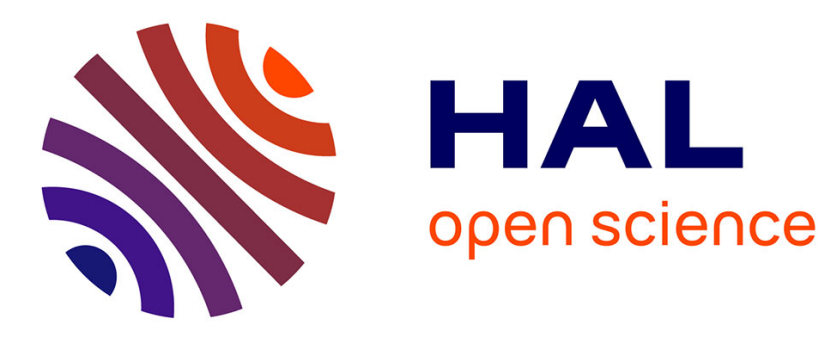

\title{
Mass wasting processes along the Owen Ridge (Northwest Indian Ocean)
}

Mathieu Rodriguez, Marc Fournier, Nicolas Chamot-Rooke, Philippe Huchon, Sébastien Zaragosi, Alain Rabaute

\section{- To cite this version:}

Mathieu Rodriguez, Marc Fournier, Nicolas Chamot-Rooke, Philippe Huchon, Sébastien Zaragosi, et al.. Mass wasting processes along the Owen Ridge (Northwest Indian Ocean). Marine Geology, 2012, pp.1-21. 10.1016/j.margeo.2012.08.008 . hal-00740983

\section{HAL Id: hal-00740983 \\ https://hal.science/hal-00740983}

Submitted on 11 Oct 2012

HAL is a multi-disciplinary open access archive for the deposit and dissemination of scientific research documents, whether they are published or not. The documents may come from teaching and research institutions in France or abroad, or from public or private research centers.
L'archive ouverte pluridisciplinaire HAL, est destinée au dépôt et à la diffusion de documents scientifiques de niveau recherche, publiés ou non, émanant des établissements d'enseignement et de recherche français ou étrangers, des laboratoires publics ou privés. 


\section{Accepted Manuscript}

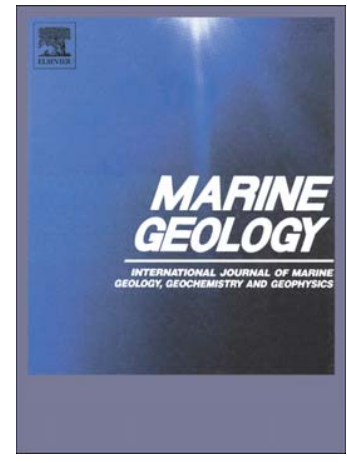

PII:

Reference:

doi: 10.1016/j.margeo.2012.08.008

MARGO 4818

To appear in: $\quad$ Marine Geology

Received date: $\quad 21$ November 2011

Revised date: $\quad 13$ June 2012

Accepted date: $\quad 3$ August 2012

Please cite this article as: Rodriguez, Mathieu, Fournier, Marc, Chamot-Rooke, Nicolas, Huchon, Philippe, Zaragosi, Sébastien, Rabaute, Alain, Mass wasting processes along the Owen Ridge (Northwest Indian Ocean), Marine Geology (2012), doi: 10.1016/j.margeo.2012.08.008

This is a PDF file of an unedited manuscript that has been accepted for publication. As a service to our customers we are providing this early version of the manuscript. The manuscript will undergo copyediting, typesetting, and review of the resulting proof before it is published in its final form. Please note that during the production process errors may be discovered which could affect the content, and all legal disclaimers that apply to the journal pertain. 
Mass wasting processes along the 0 wen Ridge (Northwest Indian 0 cean)

Mathieu Rodriguez ${ }^{1,2,3^{*}}$, Marc Fournier ${ }^{1,2}$, Nicolas Chamot-Rooke ${ }^{3}$, Philippe Huchon ${ }^{1,2}$, Sébastien Zaragosi ${ }^{4}$, Alain Rabaute ${ }^{1,2}$.

(1) Institut des Sciences de la Terre de Paris, CNRS UMR 7193, Université Pierre \& Marie Curie, case 129, 4 place Jussieu, 75005 Paris, France

(2) iSTeP, UMR 7193, CNRS, F-75005 Paris, France

(3) Laboratoire de Géologie de l'Ecole normale supérieure de Paris; CNRS UMR 8538, 24 rue Lhomond, 75005 Paris, France

(4) EPOC Université Bordeaux1, UMR 5805, avenue des facultés, 33405 Talence, France

*Corresponding author: rodriguez@geologie.ens.fr

Tel. +33144275943

Keywords : submarine landslides; Owen Ridge; Owen Fracture Zone; Indian Ocean; Arabian Sea; strike-slip fault

Abstract

The 0 wen Ridge is a prominent relief that runs parallel to the coast of 0 man in the NW Indian Ocean and is closely linked to the 0 wen Fracture Zone, an $800-\mathrm{km}$ Iong active fault system that accommodates today the Arabia-India strike-slip motion. Several types of mass failures mobilizing the pelagic cover have been mapped in details along the ridge using multibeam bathymetry and sediment echosounder. Here we present a synthetic map of the different types of mass wasting features observed along the ridge and we further establish a morphometric analysis of submarine landslides. The spatial variation of failure morphology is strongly related to the topography of the basement. The highest volumes of multi-events generated slides are mobilized along the southern portion of the ridge. There, the estimated volume of evacuated material during a slide is up to $45 \mathrm{~km}^{3}$. Combining these new observations 
with re-interpreted ODP seismic lines (Leg 117) documents sporadic mass wasting events through time along the southern segment of the ridge since its uplift in the Early Miocene, with a typical recurrence rate of the order of $10^{5}-10^{6}$ years. Although seismicity may still be the final triggering process, mass wasting frequency is mainly controlled by the slow pelagic sedimentation rates and hence, time needed to build up the $40-80 \mathrm{~m}$ thick pelagic cover required to return to a mechanically unstable pelagic cover.

\section{Introduction}

The study of mass wasting processes on continental margin has become a major topic of research during the last decades, since it plays a key role in sediment transportation to the deep ocean (Masson, 2006 and references herein). Mass wasting encompasses all gravity-driven mass movement processes. Failures affect the seabed morphology and its subsequent evolution in a variety of ways, in relation with the mechanical properties of the mobilized sediments and the large variation in volume, frequently less than one $\mathrm{km}^{3}$ but exceptionally over 20,000 $\mathrm{km}^{3}$ (Agulhas slump in SE Africa; Dingle, 1977). Although well described at continental margins (Prior, 1999; Canals et al., 2004), mass wasting along the slopes of oceanic highs standing in deep water remains poorly investigated, with the exception of the Lomonosov Ridge in the Arctic Ocean (Kristoffersen et al., 2007), the Macquarie Ridge in the South Pacific (Massel et al., 2000), and Chain Ridge off the Horn of Africa (Pimm et al., 1972). Unlike continental margins, sedimentation on these remote oceanic ridges is generally characterized by low rates of pelagic sedimentation, not directly controlled by relative sea level variations or clastic continental input. Rapid sedimentation has commonly been invoked as an important pre-conditioning factor for slope instability (Hampton et al., 1996; Lee et al., 2008), even 
though slope failure as a result of sedimentation alone seems unlikely based on theoretical grounds (Viesca and Rice, 2012). Other non-gravitational triggering factors invoked in deep-sea environments include earthquakes (Amalgor and Wisenam, 1982; Hampton et al., 1996, Mulder et al., 2009), internal waves and/or fluid (including gas) escapes (Mienert et al., 1999). To avoid any confusion, the term "failure" is hereafter used for ruptures related to mass wasting processes, and the term "fault" is used for ruptures related to tectonic processes, although both terms refer to a mechanical discontinuity in rocks.

The 2000 -m deep Owen Ridge in the NW Indian Ocean is one of these deep-water sites of widespread mass wasting where links with active tectonics can be tested. The India-Arabia plate boundary - known as the Owen Fracture Zone - runs along the ridge for more than $800 \mathrm{~km}$, where it accommodates $3 \mathrm{~mm} \mathrm{a}^{-1}$ of dextral relative motion generating moderate seismicity (Fig. 1; Fournier et al., 2008a, 2011). Both the Owen Ridge and Owen Fracture Zone were extensively surveyed during the OWEN and FANINDIEN 2009 cruises (Fig. 1) aboard the BHO Beautemps-Beaupré of the French Navy. Between $15^{\circ} \mathrm{N}$ (Beautemps-Beaupré Basin; Fournier et al., 2008b) and $22^{\circ} 30^{\prime} \mathrm{N}$ (Dalrymple Trough; Edwards et al., 2000, 2008; Gaedicke et al., 2002), the Owen Ridge is composed of three distinct bathymetric highs covered by a $\sim 500 \mathrm{~m}$ thick pelagic drape (Shipboard Scientific Party, 1989) affected by numerous submarine landslides displaying a large variety of morphological features. Here we use these newly acquired multibeam bathymetry and SBP120 (Sub-Bottom Profiler) data, together with data collected during the DSDP (Shipboard Scientific Party, 1974) and the ODP Leg 117 (Shipboard Scientific Party, 1989), to give a detailed description of mass wasting along the Owen Ridge.

The first topic of this paper is the study of spatial variations of the mass wasting process along the three segments of the Owen Ridge. The relative arrangement of slope failures and their deposits is first described to determine the variety of mass movement 
types. The evolution of the material during failure and transport is then investigated for each ridge segment. Using the method established by McAdoo et al. (2000) for bathymetric data, the volume of material mobilized at the initial stage of slope failure is estimated for each event, allowing a quantitative comparison of the erosive pattern along each of the ridge segments as well as on both sides of it. A statistical analysis of the morphological parameters of landslide scars is also performed to establish simple hypotheses regarding the origin and behaviour of failure along the Owen Ridge.

The second topic of this paper is to assess factors that control mass wasting processes through time, including triggering factors of submarine landslides. Such approach is limited to the southern Owen Ridge for which ODP data are available and allow us to date the mass transport deposits (MTDs hereafter) back to Early Miocene (Fig. 2). Whether the multi-failures landslides currently displayed on the seafloor are the product of one single catastrophic event destabilizing the entire southern ridge segment or the product of distinct and sporadic events destabilizing only limited areas is resolved by studying the relative arrangement of MTDs displayed on ODP seismic lines. The time recurrence of mass wasting events is compared with a model of earthquake recurrence along the southernmost segment of the Owen Fracture Zone to identify whether seismicity is a potential triggering factor of slope failure and MTDs a paleo-seismicity record. Slope failure frequency, together with the spatial distribution of volumes of sediment involved for each failure, allow us to discuss the preservation of submarine relief through time.

\section{Geological background}

\subsection{Geodynamic setting}

The present-day India-Arabia plate boundary in the NW Indian Ocean is located along the Owen Fracture Zone, which is an $800-\mathrm{km}$-long strike-slip fault system (Fig. 1; 
Rodriguez et al., 2011). This fault system connects the Sheba and Carlsberg ridges to the eastern end of the Makran subduction zone. Northward migration of the Arabian plate with respect to Eurasia being slightly faster than the Indian plate at this longitude, the relative plate motion is accommodated by a $3 \pm 1 \mathrm{~mm} \cdot \mathrm{a}^{-1}$ dextral component (Fournier et al., 2008a; DeMets et al., 2010). The present-day fault system has led to a finite displacement of about 10 to $12 \mathrm{~km}$ measured by morphologic offsets in the seafloor, which would indicate, at a constant rate of $3 \mathrm{~mm} \mathrm{a}^{-1}$, a Pliocene age for the youngest fault system expressed today at the seafloor (Fournier et al., 2011). Dextral motion, however, may have started as early as the Miocene (magnetic anomaly An 6, $19.7 \mathrm{Ma}$ ), as soon as spreading in the Gulf of Aden became effective (Chamot-Rooke et al., 2009; Fournier et al., 2010). The seismicity along the fault is rather low and scattered (Fig. 1), so that only few focal mechanisms are available (Quittmeyer and Kafka, 1984; Gordon and DeMets, 1989; Fournier et al., 2001). They consistently indicate pure strike-slip motion. The maximum magnitude recorded to date is a $\mathrm{M}_{\mathrm{w}} 5.3$ earthquake (Harvard CMT, 7 April 1985). However infrequent but large earthquake may be expected as at other fracture zones (Antolik et al., 2006; Robinson, 2011).

\subsection{Morphology of the Owen Ridge and sedimentary setting}

The Owen Fracture Zone follows a major morphological feature, the Owen Ridge, which is a SSW-NNE trending ridge-and-through system that may be divided - starting from the Beautemps-Beaupré Basin in the south - into five geographic provinces (Fig. 1): the southern ridge, which consists of a $300 \mathrm{~km}$-long, $50 \mathrm{~km}$-wide, up to $2000 \mathrm{~m}$-high relief (Fig. 3); the central ridge, which is a $220 \mathrm{~km}$-long, $50 \mathrm{~km}$-wide, and up to $1700 \mathrm{~m}$-high relief (Fig. 4); the $20^{\circ} \mathrm{N}$ pull apart basin; the Qalhat Seamount (or northern ridge) which is a $210 \mathrm{~km}$-long, more than $55 \mathrm{~km}$-wide, and up to $2700 \mathrm{~m}$-high relief (Fig. 5); and the 
Dalrymple Trough. The Owen Ridge topographic highs act as a barrier for the Indus turbiditic sedimentation and isolate the Owen Basin, located west of the Owen Ridge, from any sediment supply from the east (Whitmarsh, 1979; Mountain and Prell, 1990). Since its uplift in the Early Miocene (Shipboard Scientific Party, 1989), the ridge has mainly supported the deposition of a $\sim 500 \mathrm{~m}$ thick chalk and ooze pelagic blanket, and minor terrestrial input from monsoonal eddies (Clements and Prell, 2006) and oceanic jet (Ras al Hadd jet; Böhm et al., 1999; Fig. 6). The establishment of an upwelling zone in the Late Miocene induced an increase in sedimentation rates (from 8-15 $\mathrm{m} \mathrm{Ma}^{-1}$ to $54 \mathrm{~m} \mathrm{Ma}^{-1}$ ) (Mountain and Prell, 1989). Since the Pliocene, the sedimentation is mainly oozy in composition, with sedimentation rates typical of pelagic deposition (30 to $40 \mathrm{~m} \mathrm{Ma}^{-1}$ ) (Mountain and Prell, 1989; Shipboard Scientific Party, 1989), and is controlled by seasonal monsoon (Clemens and Prell, 2006).

\subsection{Geological and tectonic history of the Owen Ridge}

The present-day morphology of the Owen Ridge results from successive tectonic and volcanic events. The southern and central segments of the Owen Ridge were uplifted $\sim 19 \mathrm{Ma}$ ago, as attested by the rapid transition from turbiditic to pelagic deposits in DSDP and ODP cores (Whitmarsh et al, 1974; Shipboard Scientific Party, 1989; Weissel et al., 1992). The southern ridge appears as a large-scale tilted and relatively flat slab, interpreted as flexural response to compression (Weissel et al., 1992). Several seismic lines run as presite surveys for ODP reached the basement of the southern ridge, and show an uneven paleo-topography (Fig. 2). The substratum is basaltic in composition and of Paleocene age (Shipboard Scientific Party, 1974, 1989). Both the southern and the central ridges may have stand as positive basement features being progressively buried under turbiditic deposits during the Paleogene to Early Miocene interval, as suggested by the Oligocene 
turbiditic deposits drilled between two basement highs on the southern ridge (Fig. 2) (Shipboard Scientific Party, 1989; Clift et al., 2001; Gaedicke et al., 2002). The southern and central segments rose significantly above the level of the Indus fan to their present-day configuration following the 19 Ma uplift episode (Fig. 6).

At the northern end of the OFZ, the history of the Qalhat Seamount is not clearly established. The nature of the underlying basement remains unknown since it has never been directly sampled. The nearby presence of the Little Murray Ridge volcanic seamounts buried under the Oman basin (Gaedicke et al., 2002; Mouchot, 2009), coupled with the existence of a strong magnetic anomaly in the vicinity of the seamount and a typical flat top morphology, strongly suggest that the Qalhat Seamount is a volcanic guyot (Edwards et al., 2000; Fournier et al., 2011). Onlap of Paleocene sediments onto the Qalhat Seamount (Edwards et al., 2000, 2008; Gaedicke et al., 2002) demonstrates that the seamount is Cretaceous in age or older.

\section{Material and Methods}

\subsection{Bathymetry and sub-bottom profiles}

Swath bathymetry and backscatter data were collected using a hull-mounted Kongsberg-Simrad EM120 multibeam echosounder during the OWEN and FANINDIEN surveys (2009). Final maps were produced at an 80-m-grid interval. The vertical resolution of the swath bathymetric data is of the order of $10 \mathrm{~m}$, higher resolution being reached for vertical beams and lower resolution for far-angle lateral beams. SBP120 sub-bottom profiles were acquired along with bathymetry and reflectivity, providing a set of high frequency $(3.5 \mathrm{kHz})$ high-resolution profiles with penetration down to $100 \mathrm{~m}$ in finegrained sediments and about $25 \mathrm{~m}$ in sand-rich floor. The subsurface geology is complementary documented by ODP seismic lines along the southern Owen Ridge 
(Shipboard Scientific Party, 1989). This dataset is used to identify and map the different mass wasting types along the Owen Ridge.

\subsection{Statistical analysis of morphological parameters}

Numerous slope failures are imprinted in the present-day morphology and can directly be studied from multibeam mapping. A statistical analysis of morphometric parameters of submarine landslides was performed following the method described by McAdoo et al. (2000), which considers only multi-failures events, i.e. large failures composed of several individual failures that occurred as one single event. As an improvement of the method of McAdoo et al. (2000), we also analyse morphometric parameters of individual failures, which can be good proxies for the rheology of the mobilized material. The statistical analysis of morphometric parameters will be further used to discuss the variability of failure processes along the three segments of the Owen Ridge.

Forty-six multi-failure events have been recognized along the Owen Ridge, and almost 400 individual slope failures have been studied. A set of morphological parameters have been systematically measured: headscarp water depth, headscarp height, total area of seafloor affected by the failure, unfailed adjacent slope, runout slope, headscarp slope, and finally slide volume (Table 1). The headscarp region is the steepest slope in the eroded scar zone. The failure area is defined either as the portion of seafloor with a hummocky facies enclosed by a scar (in case of cohesive failure), or as the portion of seafloor enclosed by a scar (in case of disintegrative failure). Runout distances cannot be fully addressed because of the narrow swath available around the Owen Ridge. Table 1 summarizes correlations (covariance) between all those morphological parameters.

Following McAdoo et al. (2000), we estimated the volume mobilized in the initial stage of multi-failures events (see Table 1 for the details of the method). This volume 
estimation does not take into account the volume mobilized during mass motion. The estimation of the volume of multi-failure event is dependent on the interpretation of the timing of slope failure (see section 4).

\section{3. Estimation of mass transport deposits recurrence}

The vertical distribution of MTDs can be observed on ODP seismic lines on the southern ridge (Fig. 2) and SBP profiles on the central and the northern ridges (Fig. 7). ODP seismic lines reach the Early Miocene, whereas the penetration of SBP profiles is limited to the last $3 \mathrm{Ma}$. Age estimates used in this study are based upon ODP Leg 117, and DSDP Leg 222 bio-stratigraphic dating and sedimentation rate estimates. Sedimentation rates were used on sub-bottom profiles and on ODP seismic lines to estimate the time recorded by pelagic deposits that lie between two MTDs. Although the deposition of a MTD implies the removal of a part of the underlying pelagic cover, the time recorded by pelagic deposits is assumed to give an estimation of the time period between two MTDs. Sedimentation rates are in the range of $20-44 \mathrm{~m} \mathrm{Ma}^{-1}$ for the southern ridge from Early Miocene to Early Pliocene. From Pliocene to present, sedimentation rates for the central and northern ridges are of the order of $60 \mathrm{~m} \mathrm{Ma}^{-1}$ (DSDP site 223), and 42-53 $\mathrm{m} \mathrm{Ma}^{-1}$ (DSDP site 222), respectively. A P-wave velocity of $1500 \mathrm{~m} \mathrm{~s}^{-1}$ is used for SBP profiles to convert two-way travel time to depth. Depth dependent P-wave velocities curves from Shipboard Scientific Party (1989) are used to calibrate the thickness of sedimentary layers on ODP seismic lines.

\section{Nomenclature of mass wasting features}

Submarine landslide nomenclatures are mainly based on detailed core analyses, which reveal the large variety of mass wasting processes (Hampton et al., 1996; Mulder 
and Cochonat, 1996; Mulder and Alexander, 2002; Canals et al., 2004). In these nomenclatures, each term is related to a depositional mode. Based only on multibeam bathymetry and SBP120 data, it is difficult to determine whether a mass movement is a slump, a slide, or a debris flow, and these nomenclatures are inappropriate for these types of data (McAdoo et al., 2000; Tripsanas et al., 2008). The use of genetic nomenclatures is still more difficult in the case of multi-processes generated morphology. Indeed, different genetic processes, such as gravity instability, deformation, or sedimentary construction, may lead to quite similar sea-bottom morphology and echo-facies (see discussion for the Humboldt slide in Lee et al., 2002). Complex interaction between these processes may also be misleading (Faugères et al., 2002). Despite these drawbacks, bathymetry, sub-bottom and seismic profiles are still powerful tools to study mass wasting processes at the scale of an entire margin. Based on observations of failure geometry on bathymetry and SBP profiles, we describe the mode of slope failure development of representative field examples of each mass wasting type that we observe and map (Fig. 8), and link them to previously published nomenclatures. In absence of core analysis, the understanding of the timing of slope failure from the interpretation of SBP profiles somehow provides arguments relative to the failure processes involved.

\subsection{Cohesive failures and retrogressive slumps}

Where deposits lie at the edge of the headwall scar, the failure is mapped as "cohesive". In this case, slope deposits are enclosed by the headwall scar and display a hummocky seafloor or scattered blocks on bathymetry (Fig. 8, 10). Such deposits display chaotic and hyperbolic reflections or a transparent facies on SBP profiles (Fig. 8, see also

Fig. 5, 9, 10 for similar examples). They show as disturbed, chaotic or transparent reflectors on ODP seismic lines (Fig. 2, 9, 11). Such a description could correspond to 
slide, slump, debris avalanche, or rock fall deposits of mass wasting classifications (Mulder and Cochonat, 1996; McAdoo et al., 2000), i.e., all deposits related to the movement of a coherent mass of sediment bounded by distinct failures planes. Scattered glide blocks observed on bathymetry (Fig. 9, 10) might result from a partial disintegration of the sediment mass, but as they remain generally enclosed by the failure scar, they are included in the "cohesive" category. A particular case of "bottleneck failure" (Fig. 10) is observed along the southern Owen Ridge. Because the SBP profile shows MTD enclosed in the scar (Fig. 10), this type of failure is considered as cohesive. The term of "bottleneck failure" refers to a type of failure already defined by Prior and Coleman (1980) in the Gulf of Mexico.

Overlapping sub-parallel scars at headwall escarpments are commonly observed at the rear of a main failure scar that accommodated cohesive removal (Fig. 9, 10, 11). Such scars delineate areas of smooth or hummocky seafloor (Fig. 9, 10, 11) named hereafter as headwall collapse areas. The folded aspect of headwall collapse areas on SBP profiles can be either the result of gravitational deformation (linked to mass wasting processes) (Fig. 9) or the pelagic cover of an older irregular MTD surface at the limit of the SBP120 penetration, as seen on Fig. 11. The deep geometry of headwall collapse areas is observed on ODP seismic lines (Fig. 2, 9), which show blocks with limited down-slope total displacement along shallow listric faulting, and little internal remoulding near the headwall (Fig. 2, 9, 11).

Headwall collapse failures might either be fossil scars of previous landslides, or failures triggered subsequently to the cohesive departure of sediment, such as in retrogressive slumping events (Piper et al., 1999). In some areas (Fig. 9), the failure at the front of the headwall collapse area clearly offset MTDs on SBP profile. The headwall collapse failure thus occurred both down and up-slope the main cohesive failure plane, 
affecting MTD and pelagic deposits, respectively (Fig. 9). Such a relative chronological constrain strongly suggests that headwall collapse motion and related failures are a subsequent response to the steep slope created by the cohesive mass departure.

An other interpretation is suggested by the failure exposed in Figure 11. The ODP seismic line shows two distinct MTDs, the older one being covered by thicker pelagic deposits. The younger scar is located downslope the older one, suggesting a progressive erosion of the slope in this area.

Where cohesive failures are closely related to headwall collapse areas, they are thus interpreted as occurring as one single retrogressive slump event, consistently with previous works on similar failures (Grand Banks (Piper et al., 1999), Cretan margin (Strozyk et al., 2010), Storegga slide (Kvalstad et al., 2005)), excepted in the area illustrated in Figure 11.

\subsection{Disintegrative failure features}

Where there are no obvious landslide deposits at the base of the scar or in the area enclosed by the scar, the failure is mapped as "disintegrative". The seafloor enclosed by the scar is smooth on bathymetry (Fig. 8). Reflectors display a rough facies on SBP profiles, as the result of the erosion related to the motion of the destabilized mass (Fig. 8, 12). The sediment mass could have lost its cohesion either during failure, or by incorporating fluids during the down-slope movement of the mass. This second category relates to debris flow and grain flow in the classification of Mulder and Cochonat (1996).

Disintegrative failures observed along the Owen Ridge include arcuate failures (Fig. 8), evacuation pathways (Fig. 8, see also Fig. 5, 12, 13, 14 for other examples), and gullies (Fig. 13). Arcuate failures show a semi-circular, concave-upward shape (Fig. 8). The term of evacuation pathway refers to very elongate, rectilinear scars that erode previously deposed MTDs located down-slope, as shown on several SBP profiles (Fig. 8). 
Gullies are forming by multiple small-scale episodes of retrogressive sedimentary removal (Fig. 13) and can be considered as a particular case of disintegrative failure, as no MTD lie in the area enclosed by the scar. Where deposits are identified outside of the area enclosed by the scar, they are mapped under the general term of MTDs.

\subsection{Potentially multi-processes generated features}

Two morphological features that could be the result of the interaction of slope instability with other processes (such as bottom currents or fluid escapes) were further identified along the Owen Ridge: undulating seafloor (Figures 3, 4, 5, 8) and sub-circular depressions (Fig. 5, 8). Some authors identify undulating seafloor features as deformation structures, creep and/or early indication of slope instability (Lee et al., 1981; Field and Barber, 1993; Baraza and Ercilla, 1996; Gardner et al., 1999; Corregiari et al., 2001; Lee et al., 2002), or as the result of a combination of deformation and depositional processes (Faugères et al., 2001; Gonthier et al., 2002; Shillington et al., 2012). Sub-circular depressions similar to the ones observed along the Owen Ridge are described on the Malpelo Ridge (Lonsdale and Fornari, 1980) and on the Carnegie Ridge (Michaud et al., 2005) in the Pacific Ocean. Various origins have been proposed by Michaud et al. (2005), including underwater dissolution, submarine currents, fluid escape (such as in pockmarks features) and creeping. However, it is not possible to discriminate if slope instability is the dominant genetic process for the formation of these seafloor undulations and sub-circular depressions without geotechnical data (Sultan et al., 2008). Therefore, these two features are mapped but not discussed.

\section{Results}


Mass wasting affects the three topographic highs of the Owen Ridge in different ways and to different degrees. For each ridge segment, we first describe the large-scale morphology of the Owen Ridge and the distribution of failure volumes. We then describe the distribution of each mass movement type on both sides of each segment. Stratigraphic data from ODP Leg 117 are also used to assess the vertical distribution of MTDs. The tectonics of the Owen Fracture Zone is detailed in Rodriguez et al. (2011), but where necessary we describe the relationship between the MTDs and the surface traces of the active faults. In the following, the term of open-slope type means that no topographic barrier obstructs mass movement once initiated. The term of "intra-canyon" erosive pattern means that the local topography influences the evolution of mass movements, similarly to canyons that dissect passive margins.

\subsection{Mass wasting along the southern Owen Ridge}

The southern ridge is an asymmetric relief, with a steep east-facing scarp associated with the Owen Fracture Zone and a regular western slope corresponding to sedimentary beds gently tilted $3^{\circ}$ to the west (Fig. 3; Shipboard Scientific Party, 1989). The environment is thus of open-slope type. However, the contrast in slopes correlates with a contrast in types of mass wasting found on both sides of the ridge. The morphology of the western slope generally favours retrogressive slumps, with large volume failures (up to $\sim 40 \mathrm{~km}^{3}$, Fig. 15), and long transport distances (up to $40 \mathrm{~km}$ ). On the other hand, gullies dominantly erode the steeper and shorter flank to the east (Arabian Sea side), although block falls and cohesive deposits are locally observed at the foot of the main slope and locally beyond the active fault trace (Fig. 3).

With regards to the volumes of a multi-failure generated event, the western slope of the southern ridge is characterized by the highest number of events $(n=25)$ involving more 
than $1 \mathrm{~km}^{3}$ of material (Fig. 15). The southern ridge also displays the largest landslides, with 9 events extending over $100 \mathrm{~km}^{2}$ or more. Retrogressive slumps are the dominant mode of mass wasting on the western slope ( $40 \%$ of the southern ridge area). Cohesive failures are mostly arcuate, with various length comprised between $7.9 \mathrm{~km}$ and $41.4 \mathrm{~km}$, and large runout distances $(>30 \mathrm{~km})$ (Fig. 3). The associated headwall collapse areas range from 3 to $240 \mathrm{~km}^{2}$ (Fig. 3, 9, 10, 11). Several glide blocks, with sizes varying between $10^{4}$ and $1.5 \times 10^{7} \mathrm{~m}^{3}$, have been identified close to headwall collapse failures (Fig. 9, 10). In some areas, the scar related to the glide blocks is meshed in the headwall collapse failure, suggesting that those block falls could have been triggered by the headwall collapse motion after the mass departure (Fig. 9). Scarps heights created by headwall collapse motion cluster between $20 \mathrm{~m}$ and $90 \mathrm{~m}$, but can locally reach $140 \mathrm{~m}$ when associated with glide blocks (Fig. 9, 10). One particular case of bottleneck slide is observed around $16^{\circ} \mathrm{N}$ (Fig. 10).

Disintegrative failures show arcuate (Fig. 3), and elongate scars (Fig. 9, 10, 12). Arcuate disintegrative scars are isolated along the southern ridge, and occur mainly at the edge of headwall collapse areas (Fig. 3), whereas elongate scars occur preferentially downslope (between 2600 and $3400 \mathrm{~m}$ depth) in areas of hummocky seafloor (Figures 3, 8, 9, 12), where they form coalescing failures (Fig. 8, 9, 12). They accommodate superficial erosion, with base of the failure rooted between 20 and 40 meters below sea-floor. Elongate scars mobilize volumes ranging between 0.07 to $3 \mathrm{~km}^{3}$.

The northern end of the southern ridge displays a particular mode of slope failure, with the two largest failures of the Owen Ridge, which are located between $17^{\circ} 20^{\prime} \mathrm{N}$ (Fig. 8) and $17^{\circ} 40^{\prime} \mathrm{N}$ (Fig. 12). In the area of the $17^{\circ} 20^{\prime} \mathrm{N}$ landslide, a $400 \mathrm{~km}^{2}$ area of hummocky seafloor, characterized by a chaotic facies on echo-sounder profiles (SBP120), is partly enclosed by a $35 \mathrm{~km}$-long arcuate failure scar (Fig. 8), suggesting a cohesive 
motion of the transported mass. The $17^{\circ} 20^{\prime} \mathrm{N}$ landslide may have mobilized $40 \mathrm{~km}^{3}$ of pelagic material during the initial stage of failure. The landslide located between $17^{\circ} 30^{\prime} \mathrm{N}$ and $17^{\circ} 45^{\prime} \mathrm{N}$ is more complex and shows multiple and sinuous failure scars (Fig. 12). The main failure encloses a $\sim 430 \mathrm{~km}^{2}$ area of hummocky seafloor. It is unclear if the hummocky area is the product of a single multi-failure event covering older elongate scars, or if it is the product of several generations of elongate failures. According to the first hypothesis, the failure may have mobilized $45 \mathrm{~km}^{3}$ of pelagic material during the initial stage of failure. The hummocky area partially covers the proximal part of elongate scars A and B located down-slope (Fig. 12). Thus, elongate scars observed down-slope predate the cohesive failure that was triggered up-slope. The SBP profile shown in Figure 12 shows that the pelagic layer that covers the area enclosed by the elongate scar B is thicker than for the area enclosed by elongate scar A (Fig. 12). This is consistent with several generations of elongate failures dissecting the slope.

The "open-slope" erosive pattern described above vanishes at the latitude of $16^{\circ} 10^{\prime} \mathrm{N}$, where an "intra-canyon" erosive pattern is observed (Fig. 11). The slope displays an amphitheatre shape dissected by complex network of coalescing arcuate scars and headwall collapse up-slope (Figures 3 and 11). Fluid outlets are locally observed on SBP120 profiles (Fig. 11). In this area, gliding planes are parallel to the stratigraphic bedding, and sometimes seem to jump between different stratigraphic levels when approaching the headwall of the slides (Fig. 2).

In addition to subsurface analysis, ODP data highlights the stratigraphy of mass transport deposits since the Early Miocene. The extension of ODP seismic lines does not cover the entire southern segment, and does not allow the estimate of volumes of buried MTDs. However, ODP and DSDP reporters noticed several hiatuses along the ridge that they interpreted as consecutive to slump removals (Shipboard Scientific Party, 1989). 
Missing thicknesses of material range from 50 to $150 \mathrm{~m}$, and locally removed up to $5 \mathrm{Ma}$ of sedimentation history. Over 60 MTDs facies are evidenced on ODP seismic data, which may represent $\sim 30$ failures events that have affected the pelagic cover. (Fig. 2; Shipboard Scientific Party, 1989). This is a minimum number, since only major MTDs are identified because of the low resolution of the ODP seismic lines. Truncated reflectors allow us to identify erosive surfaces due to mass departures. These MTDs are difficult to date using seismic correlation with ODP cores, due to faulting above substratum highs. However, mass wasting events along the southern ridge are mainly asynchronous, since they are covered by pelagic reflectors of various ages (Fig. 2). Only two coeval events are observed on seismic line 29 (Fig. 2). In some places, the same glide plane is associated with several MTDs (Fig. 2). Those deep failure glide planes are located above basement highs and delineate major mass wasting areas (Fig. 2). Thicknesses of MTDs measured from ODP seismic since Early Miocene range from $30 \mathrm{~m}$ to $220 \mathrm{~m}$, which is consistent with thicknesses measured on SBP profiles for the most recent MTDs. Thicknesses of MTDs increase downward the slope, suggesting the erosion and the capture of superficial material (Fig. 2).

The crude frequency of major mass wasting events can be estimated from the study of the pelagic interval between two superposed MTDs. The thickness of pelagic interval ranges between 25 to $170 \mathrm{~m}$, which would correspond to a periodicity of 0.6 to $4.2 \mathrm{Ma}$ for the very large events over the unstable areas (using a standard sedimentation rate of $40 \mathrm{~m} \mathrm{Ma}^{-1}$ ). In contrast, some areas along the southern ridge seem to be totally devoid of large MTDs since the Early Miocene (Fig. 2).

5.2. Mass wasting along the central Owen Ridge 
The central ridge displays an irregular morphology, with a 2400 m-deep plateau spreading over $485 \mathrm{~km}^{2}$ (Fig. 4). The irregular morphology is mainly associated with an "intra-canyon" pattern of slope failure. Complex networks of gullies dissect both the western and the eastern side of the ridge. They locally merge down-slope into evacuation pathways on the western side (Fig. 13). This failure pattern is characterized by a strong correlation between headscarp height and headscarp slope and an anti-correlation between the headscarp height and its depth of initiation (Table 1).

Some conspicuous failures are observed on the western flank of the central ridge. One of them is the disintegrative failure located at $19^{\circ} \mathrm{N}$ (Fig. 13, failure A), which is composed of three main coalescing and indented scars. Another particular failure is the curved and cohesive slide observed northward, at the latitude of $19^{\circ} 15^{\prime} \mathrm{N}$ (Fig. 13, failure B). Its seafloor signature is composed of three overlapping major scars. Initially E-W oriented, the slump course bends southwards when moving downslope. A last example of conspicuous erosive network extends in the area between $19^{\circ} 20^{\prime} \mathrm{N}$ and $19^{\circ} 35^{\prime} \mathrm{N}$. Superficial disintegrative flows mainly dissect this area, mobilizing 0.003 to $0.03 \mathrm{~km}^{3}$ of sediments. The most noticeable feature is a $2530 \mathrm{~m}$ wide (at the mouth), $9630 \mathrm{~m}$-long elongate scar which removed $0.39 \mathrm{~km}^{3}$ of material (Fig. 14).

Three stacked MTDs are observed on SBP profile at the southern foot of the central ridge (Fig. 7). The thickness of pelagic intervals gives return periods of 64 to $108 \mathrm{ka}$.

\subsection{Mass wasting along the northern Owen Ridge (Qalhat Seamount)}

The top region of the Qalhat Seamount is flat and stable over an area of $1210 \mathrm{~km}^{2}$. Between $20^{\circ} 30^{\prime} \mathrm{N}$ and $21^{\circ} 30^{\prime} \mathrm{N}$, the northern ridge displays an irregular morphology being eroded on its flank by complex networks of gullies, and evacuation pathways (Fig. 5). 
Similarly to the central ridge, morphological parameters of failure show a strong correlation between the headscarp height and the headscarp slope (Table 1).

Gullies networks are complex on the Qalhat Seamount. They initiate at different water depths (between -400 and $-1800 \mathrm{~m}$ ), and display short dendritic network at their head, that rapidly merge into rectilinear evacuation pathways (Fig. 5). Disintegrative failure events within gullies networks removed up to $3.72 \mathrm{~km}^{3}$ of sediments. Between $20^{\circ} 50^{\prime} \mathrm{N}$ and $21^{\circ} 10^{\prime} \mathrm{N}$, gullies merge into a semi-circular (amphitheatre shape) evacuation pathways system that extends over a $1730 \mathrm{~km}^{2}$ area (Fig. 5). All evacuation pathways initiated by mass wasting processes in the amphitheatre merge in a single one at $3000 \mathrm{~m}$ water depth. This gathering evacuation pathway is $8.5 \mathrm{~km}$ wide at its mouth, and connected to the east with the Qalhat pull-apart Basin along the Owen Fracture Zone. A complex multi-retrogressive failure composed of coalescing scars is located where the major evacuation pathways of the northern ridge merge with the Qalhat Basin (Fig. 5). Volumes of sediment mobilized by these failures range from 0.03 to $0.86 \mathrm{~km}^{3}$.

Two major disintegrative failures are observed on the $2.5^{\circ}$ steep southern flank of the Qalhat Seamount (Fig. 5and 8). They mobilized 0.5 and $0.17 \mathrm{~km}^{3}$ of material. Four related MTDs are stacked on SBP profile (Fig. 7) at the foot of the Qalhat Seamount (Fig. 7). The thickness of pelagic intervals between MTDs gives return periods ranging between 29 and $178 \mathrm{ka}$.

\section{Discussion}

6.1. Modes of slope failure along the Owen Ridge

The location of the largest failures is not controlled by the trace of the Owen Fracture Zone. The modal value of the volumes mobilized by individual slides is quite similar for the three ridges $\left(0.05 \mathrm{~km}^{3}\right.$; Fig. 15), which is consistent with the fact that 
failures affect the same pelagic material along the entire ridge. However, the southern ridge displays the largest failure areas and the most voluminous landslides. This means that the "open slope" setting, due to the tilted pelagic banks configuration, allows the mobilization of large slope areas by the same failure plane and favours the evolution of slope failure into large landslides. This configuration also favours the departure of large cohesive masses necessary to trigger headwall collapse motion, and therefore retrogressive slumping. On the other hand, the "intra-canyon" pattern of the central ridge prevents the evolution of large slope failures. The "open slope" pattern of mass wasting along the southern ridge thus contrasts with the "intra-canyon" pattern displayed by the central and northern ridges.

Correlative relationships of the morphological parameters of slope failure give indications about the failure mechanism. Correlations between the morphological parameters do not reveal peculiar failure behaviour on the western side of the southern Owen Ridge (Table 1). Both the central and the northern ridges show a good correlation $(>0.6)$ between headscarp height and headscarp slope (Table 1). McAdoo et al. (2000) suggested that headscarp height and slope may be used as a proxies for sediment strength, steeper and higher scarps indicating sediment overconsolidation and higher dynamic strengths. On the central ridge, there is an anti-correlation between the headscarp height and its depth of initiation, hence suggesting a lower cohesion of the material removed downslope. This is consistent with observations of MTDs being removed by an elongate disintegrative failure on SBP profile (Fig. 13). Evacuation pathways on the western side of the central ridge are likely to remobilize MTDs from the gullies network above (Fig. 4, 13). On the northern ridge, the semi-circular evacuation zone cuts into several generations of stacked MTDs (Fig. 5), suggesting it removes previously unconsolidated deposits too. Moreover, slope failures display irregular morphology, such as the curved scars observed 
on the central ridge (Fig. 13). Thus, steep slopes created by the uneven topography of the basement favours irregular-shaped, frequent and small-scale failures, whose deposits are remobilized downslope by larger, and more elongate failures, which compose evacuation pathways.

\subsection{Influence of the pre-uplift topography of the Owen Ridge}

The topography of the southern Owen Ridge before its uplift is identified on ODP seismic lines (Fig. 2). During the Paleocene to Early Miocene interval, the Indus turbiditic system progressively smoothed the uneven topography of the southern ridge (Fig. 2) (Shipboard Scientific Party, 1989), and predisposed a relatively flat substratum for the subsequent pelagic cover. The small areas of basement features that used to stand above the seafloor before the uplift define and isolate several areas of "open slope" failure, which do not fail synchronously, and where the recurrence of MTDs is different (Fig. 2). The only area where mass wasting processes display an "intra-canyon" pattern (Fig. 11) is located where the distance between two basement highs is the smallest (Fig. 2). Moreover, the pre-uplift topography strongly controls the location of failure glide planes, which are reactivated through time (Fig. 2, 9). In areas delimitated by basement highs, fluid escape may also act as a pre-conditioning factor of slope instability and play a role in the difference in failure distribution between two areas.

On the other hand, the guyot morphology of the Qalhat Seamount indicates that its paleo-topography was close to the sea level, thus preserved from turbiditic burial. Similarly, the pre-20 Ma uplift topography of the central ridge was probably higher than the southern segment during the same period and has been partly preserved from turbiditic burial (Fig. 6). This configuration thus predisposed an "intra-canyon" pattern for the erosion of the pelagic cover of the central and northern ridges. The variation in the 
topography of the Owen Ridge before its uplift is thus partly responsible for the variety of mass wasting features observed.

\subsection{Recurrence interval and triggering mechanisms of slope failure}

Seismicity is frequently invoked as a triggering factor for slope failures in deep-sea environments. Earthquakes add to ambient gravitational forces by generating horizontal and vertical ground accelerations, while simultaneously increasing pore fluid pressure (Almagor and Wisenam, 1982; Hampton et al., 1996). The seismicity along the Owen Fracture Zone might be the triggering process of slope instability. However, the seismicity reported for the last 40 years is negligible: the total seismic moment release sums to 1.5 $10^{18}$ N.m for the entire strike-slip portion of the fault (more than $700 \mathrm{~km}$ ), which is equivalent to the seismic release of a single $M_{w} 6$ earthquake. Rupturing the southern segment of the fault (120-km-long; Fournier et al., 2011) would require a $\mathrm{M}_{\mathrm{w}}>6.5$ earthquake if the recurrence time is $10^{2}$ years, and several earthquakes of that size would be required to break the entire fault system (Fig. 16). Yet, the centennial earthquake catalogue (Engdahl et al., 1998) (supposed to be complete down to magnitude 7 earthquakes) does not report any significant event along the Owen Fracture Zone. One possibility is that the recurrence time is significantly longer, and that the Owen Fracture Zone is presently in an interseismic loading stage. If the recurrence time is $10^{3}$ years or greater, then earthquakes with $\mathrm{M}_{\mathrm{w}}>7.7$ would be expected. Although the structure of the Owen Fracture Zone was probably not the same as in present day during the Early Miocene to Late Pliocene period, we hypothesize that fault segments of similar lengths could have ruptured. The estimate of earthquake recurrence (Fig. 16) shows that rupturing the southern fragment of the fault (120-km-long) would require an $\mathrm{M}_{\mathrm{w}}>7$ earthquake for 
recurrence intervals ranging between $10^{2}-10^{3}$ years. This earthquake recurrence estimate does not fit with the observed landslide frequency, of the order of $10^{5}-10^{6}$ years.

Since the Early Miocene, the modal thickness of removed material on the southern ridge is $80 \mathrm{~m}$, and it is rare that more than two slides occurred at the same location at different times (Fig. 2). In spite of the slow pelagic deposition (2 to $2.5 \mathrm{Ma}$ are necessary to accumulate $80 \mathrm{~m}$ of sediments), the scarcity of mass wasting events at a given location, together with dominantly cohesive motion and short transport distances (an important fraction of MTDs remains on the ridge and does not reach the Owen Basin (Fig. 2)), provides the durability of the sedimentary system. If slides of these magnitudes occurred after each earthquake, there would be very little pelagic cover remaining after a few events. As a result, large magnitude earthquakes may still be the dominant triggering process, but slow sedimentation rates restrict landslide frequency. If the pelagic sedimentary load is not sufficient, then it could not be mobilized during an earthquake. With regards to the central and the northern ridges, the failure at a given location seems to be more frequent, but involves smaller volumes than on the southern ridge (Fig. 15). Steep slopes may reduce the accumulation of sediments, and increase mass wasting frequency. This erosive pattern seems to preserve the pelagic cover too.

\subsection{Comparison with continental margins}

Volumes of landslides over the Owen Ridge compare closely to continental margins. The largest landslides on the Owen Ridge occur in areas where the slope gradient is low $\left(2-3^{\circ}\right)$, which is consistent with other observations of large landslides occurring on low mean seafloor slope angles (Canals et al., 2004). Similarly to the Owen Ridge, landslides volumes estimated over the US continental slope range between less than 0.1 
$\mathrm{km}^{3}$ to $42.5 \mathrm{~km}^{3}$, except in the Gulf of Mexico where volumes reach $150 \mathrm{~km}^{3}$ (McAdoo et al., 2000, 2004; Chaytor et al., 2009, Twichell et al., 2009).

The comparison with landslides at convergent margins, which are frequently affected by high magnitude earthquakes and supplied by important sedimentation rates $(>100 \mathrm{~m} / \mathrm{Ma})$, offers an interesting perspective. The Algerian margin, which undergoes frequent earthquakes, displays small landslides (with a maximal volume of $0.20 \mathrm{~km}^{3}$ ) (Dan et al., 2010) compared to the Owen Ridge. On the other hand, volumes of landslides in the Cascadia area, which is supplied by abundant sedimentary material and submitted to infrequent but high magnitude earthquakes, compare closely with volumes estimated along the Owen Ridge, with volumes up to $42.5 \mathrm{~km}^{3}$ according to McAdoo et al. $(2000,2004)$. Recent studies in the area of the $M w=8.8$ Maule earthquake of the 27 February 2010 offshore Chile shows that only small scale slides where produced by the earthquake and its aftershocks (Völker et al., 2011). Similar conclusions have been proposed for the Hellenic arc (Strozyck et al., 2010) or Sumatra (Tappin et al., 2007). It thus appears that areas with frequent shaking and important sedimentation rates $(>100 \mathrm{~m} / \mathrm{Ma})$ do not provide the most voluminous landslides.

In the case of the Southern Owen Ridge, the restriction imposed on landslide frequency by slow pelagic sedimentation rates favours the mobilization of quite large volumes, and limits the occurrence of small-scale landslides. The poor sedimentary supply to the Owen Ridge, together with the low rate $(\sim 1$ event/ka) of strong magnitude earthquakes $\left(M_{\mathrm{w}}>6\right)$ that could shake hard enough the seafloor to trigger mass wasting, probably explain why large failure scars are preserved on the seafloor.

\section{Conclusions}


The three segments of the Owen Ridge display a large variety of mass wasting features strongly constrained by the basement topography. The uneven topography of the basement of the southern ridge has been partly smoothed by turbiditic deposits. This allowed the deposition of horizontal and parallel pelagic beds over wide areas. As a result the southern Owen Ridge displays an "open-slope" pattern, which favours the development of large but infrequent landslides. The landslide morphology on the southern ridge is the result of distinct and sporadic events, and not of a giant failure mobilizing the pelagic cover over the entire length of the southern ridge. In this area, slope failures remove up to $\sim 40-45 \mathrm{~km}^{3}$ of pelagic material, which compare closely to the volume estimated for some continental margins (McAdoo et al., 2000), but these events are far less frequent on the Owen Ridge. On the other hand, the steeper slopes of the central and northern ridges favour smaller but more frequent slides. In spite of different mass wasting pattern in space and in time, the pelagic cover over the three segments of the Owen Ridge is preserved. Our study demonstrates that earthquakes are more frequent than landslides, leading to the interpretation that mass-wasting frequency is strongly limited by sedimentation rates. It remains unknown how the volumes of buried MTDs observed on ODP seismic lines compare with the volumes of the initial stages of failures estimated from the morphology imprinted on the seafloor.

Acknowledgements: We are indebted to the Captain Geoffroy de Kersauson, officers and crewmembers of the BHO Beautemps-Beaupré, and to the French Navy hydrographers Vincent Lamarre and Yves-Marie Tanguy, and the hydrographic team of the 'Groupe Océanographique de l'Atlantique', for their assistance in data acquisition. We greatly acknowledge the editor D.J.W. Piper, D. R. Tappin, and three anonymous reviewers for their helpful and constructive comments. We thank Patrick Meunier, 
Siegfried Lallemant, and Rob Viesca for their interest in our work and their suggestions, and Baptiste Mulot and Pierpaolo Dubernet for their technical assistance. We acknowledge the support of SHOM, IFREMER, CEA and INSU-CNRS for the Owen cruise. 
Figure captions

Table 1. Correlation coefficients (covariance) for the morphometric parameters of slope failures along the Owen Ridge. All of the measured and calculated variables are correlated to explore possible relationships. Coefficients greater than or equal to 0.5 are highlighted in bold and yellow. Coefficients used to discuss failure mechanisms are highlighted in green.

Figure 1. Multibeam bathymetry of the study area acquired during the AOC 2006, OWEN and FANINDIEN 2009 cruises, with location of figures 3, 4 and 5. Inset shows the regional setting of the India-Arabia plate boundary. Crustal seismicity since 1973 (focal depth $<50 \mathrm{~km}$, magnitude $\mathrm{M}_{\mathrm{w}}>2$ ) is from the USGS/NEIC database (yellow dot), Engdhal et al. (1998, white dot), CMT Harvard database (red dot), and Quittmeyer and Kafka (1984; green dot). AOC: Aden-Owen-Carlsberg triple junction, B ${ }^{3}$ : BeautempsBeaupré Basin, ITS: Indus turbiditic system, OFZ: Owen Fracture Zone, Sh: Sheba Ridge. The three boxes correspond to the segmentation of the Owen Ridge (southern, central, and northern segments) used throughout the text.

Figure 2. Seismic lines collected during the ODP Leg 117 (Shipboard Scientific Party, 1989) and their new interpretation, with special emphasises on mass wasting events. Dotted line U1 marks the earliest uplift of the Owen Ridge in Early Miocene (ca. 19 Ma) and images the pre-uplift topography of the southern ridge. Dotted line U2 marks the facies change from turbidites to pelagic sediments at about $15 \mathrm{Ma}$. Inset on the right hand corner shows the location of ODP seismic profiles.

Insets A and B are close-up of portions of seismic lines 32 and 29, respectively. 
Figure 3. A) Bird's eye view of the southern ridge with $200-\mathrm{m}$ interval bathymetric contours, and main seabed features. B) Slope map of the southern Owen Ridge with location of figures $8 \mathrm{~A}$ and $\mathrm{B}$, and 9 to 12 , and synthetic map of the different types of mass wasting observed.

Figure 4. A) Bird's eye view of the central ridge with 200-m interval bathymetric contours, and main seabed features. B) Slope map of the central Owen Ridge with location of figures 7A, 8E , 13 and 14, and synthetic map of the different types of mass wasting mode observed.

Figure 5. A) Bird's eye view of the Qalhat seamount with 200-m interval bathymetric contours, and main seabed features. B). Slope map of the Qalhat Seamount with location of figures $7 \mathrm{~B}$ and $8 \mathrm{D}$, and synthetic map of the different types of mass wasting mode observed. Inset 1 shows networks of gullies, which display short dendritic network at its head, that rapidly merge into rectilinear evacuation pathways. Inset 2 shows gullies locally cutting into a slump deposit, which shows an undulated seafloor evolving down-slope into an irregular morphology, composed of coalescing and irregular circular depressions. C) 3.5 $\mathrm{kHz}$ profiles showing several generations of MTDs merging in the evacuation zone (see B for location).

Figure 6. Perspective views of the sedimentary system of the Owen Ridge before the uplift (bottom) and at present (top). Both the Qalhat Seamount and the Central Ridge stood above the Indus abyssal plain $20 \mathrm{Ma}$ ago. Sediment waves on the Oman continental shelf are generated by the Ras al Hadd Jet. CR: Central Ridge, MO: Masirah Ophiolites, OFZ: Owen Fracture Zone, QS: Qalhat Seamount, SR: Southern Ridge. 
Figure 7. $3.5 \mathrm{kHz}$ profiles showing A) several lenses of MTDs related to the erosion of the southern flank of the central Owen Ridge by disintegrative failures and B) MTDs related to the erosion of the southern flank of the Qalhat Seamount by disintegrative failures (see Figures 4 and 5 for location, respectively).

Figure 8. Synthesis of EM120 swath bathymetry (slope map) features, $3.5 \mathrm{kHz}$ echo-facies and their interpretation. The cohesive failure category is illustrated by the landslide located at $17^{\circ} 20^{\prime} \mathrm{N}$ on the southern ridge (see Fig. 3 for location). A hummocky seafloor area is enclosed in a failure scar. SBP profiles crossing the hummocky seafloor area shows chaotic to transparent reflections, which relates hummocky seafloor to areas of MTDs. This category of failure is complementary illustrated in Fig. 9 to 13). The disintegrative failure category is illustrated by two field examples. Elongate failures displayed on example A are located down-slope the western flank of the southern ridge (see Fig. 9). The SBP profile shows an elongate scar that eroded previously deposed MTDs. Arcuate failures displayed on example B are located on the southern flank of the Qalhat seamount (see Fig. 5 for location). MTDs are not observed in areas enclosed by a scar, but down-slope. This category is further illustrated in Fig. 5, 9, 12 and 13). The "multi-processes generated features" category is illustrated by two field examples. The undulating seafloor area displayed on example A is located on the western flank of the Qalhat Seamount (Fig. 5). It could be either the result of slump processes, or the result of bottom currents, or both of these processes. The sub-circular features displayed on example B are located on the top of the central ridge (Fig. 4). They could be either the result of fluid escape, carbonate dissolution, or early stages of slope destabilisation. See section 4 in text for detailed explanations. 
Figure 9. A) Slope map of a multi-event generated scar on the southern Owen Ridge, showing the main slump scar and the related headwall collapse at the rear, with some block fall associated to the headwall collapse (see Fig. 3 for location). B) SBP profile crossing an headwall collapse area, and C) the related ODP seismic line (see Fig. A for location). D) $3.5 \mathrm{kHz}$ profile showing MTD faulted by headwall collapse fault, and gently disturbed pelagic drape within the headwall collapse area (see Fig. A for location).

Figure 10. A) Slope map of a multi-event generated scar on the southern Owen Ridge, showing a bottleneck scar (see Fig. 3 for location). Bottleneck scars are characterized by narrow opening (1000 $\mathrm{m}$ to $2760 \mathrm{~m}$ ) at their mouth, through which a part of the cohesive flow is discharged. B) $3.5 \mathrm{kHz}$ profile crossing the bottleneck scar and adjacent mass transport deposits (see A for location).

Figure 11. A) Slope map of a multi-event generated scar on the southern Owen Ridge, showing the main slump scar and the related headwall collapse at the rear; and an area of "intra-canyon" failure pattern (see Fig. 3 for location). B) ODP seismic line crossing headwall collapse area (see Fig. A for location). $3.5 \mathrm{kHz}$ profiles showing C) fluid escape features and D) folded reflectors in the headwall collapse area, similarly to the ODP seismic line in B) (see A for location).

Figure 12. A) Slope map of the largest multi-event generated scar on the southern Owen Ridge, with elongate scars buried under MTDs (see Fig. 3 for location). B) $3.5 \mathrm{kHz}$ profile crossing a disintegrative elongate failure buried under a thicker pelagic cover than the surrounding MTDs (see A for location). 
Figure 13. A) Slope map of the central Owen Ridge, showing "intra-canyon" failure pattern on the western side and complex networks of gullies (see Fig. 5 for location). B) and C) Bird's eye views failure A and B, respectively, with 200-m interval bathymetric contours (vertical exaggeration $\mathrm{x} 6$ ). D) $3.5 \mathrm{kHz}$ profile showing slump deposits remobilized by disintegrative failures. E) $3.5 \mathrm{kHz}$ profile crossing the curved scar (see Fig. A for location). Failure A results from the coalescence of three slides with volume ranging from $0.15 \mathrm{~km}^{3}$ to $0.8 \mathrm{~km}^{3}$. These slides are characterized by an indented shape, which results from the merging of several 840 to $1620 \mathrm{~m}$ wide half-rounded scars, mobilizing volumes between 0.006 and $0.013 \mathrm{~km}^{3}$. Failure B is also the result of three overlapping scars. A smooth seafloor aspect characterizes the first scar, whereas the $3.5 \mathrm{kHz}$ profile reveals the presence of a $30 \mathrm{~m}$ thick MTD buried underneath a thin pelagic cover enclosed by the scar. The second scar is curved and encloses MTDs. Three generations of nearly $10 \mathrm{~m}$-thick MTDs are inserted within the pelagic cover. Downslope, the third failure is disintegrative and is composed of small coalescing gullies.

Figure 14. Slope map of the central Owen Ridge, showing elongate disintegrative failures (see Fig. 5 for location).

Figure 15 . A) Distribution of the volumes of individual failure according to the mode of failure (gullies, cohesive and disintegrative) for each segment of the Owen Ridge. B) Volumes distribution for multi- failures events along the Owen Ridge. 
Figure 16. Estimation of earthquake recurrence along the segment of the OFZ crossing the southern ridge. Co-seismic slips along the OFZ and expected earthquake magnitude are expressed according to the shear rate (x axis) and the interseismic loading time (y axis). The domain of shear rate estimated for the OFZ $\left(3 \pm 1 \mathrm{~mm} \cdot \mathrm{a}^{-1}\right)$ is outlined by the green area. See text for detailed explanations. 
References

Almagor, G., Wisenam, G.H., 1982. Submarine slumping in the continental slope of Israel. In: Saxov, S., Nieuwenhuis, J.K. (Eds.), Marine Slides and other mass movements, Proc of a NATO Workshop on Marine Slides and Other Mass Movements, Algarve, Portugal,1521 dec. 1980, ser. 4, vol. 6, pp. 95-128.

Antolik M., Abercrombie, R.E., Pan, J., Ekström G., 2006. Rupture characteristics of the $2003 \mathrm{Mw} 7.6$ mid-Indian Ocean earthquake: Implications for seismic properties of young oceanic lithosphere, Journal of Geophysical Research, 111, B04302, doi:10.1029/2005JB003785

Baraza, J., Ercilla, G., 1996. Gas charged sediments and large pockmark-like features on the Gulf of Cadiz slope (SW Spain), Marine and Petroleum Geology 13, 253-261.

Böhm, E., Morrison, J.M., Manghnani, V, Kim, H.-S, Flagget, C.N., 1999. The Ras al Hadd Jet: Remotely sensed and acoustic Doppler current profiler observations in 1994-1995. Deep-Sea Research II 46, 1531-1549.

Canals, M., Lastras, G., Urgeles, R., Casamor, J.L., Mienert, J., Cattaneo, A., De Batist, M., Haflidason, H., Imbo, Y., Laberg, J.S., Locat, J, Long, D., Longva, O., Masson, D.G., Sultan, N., Trincardi, F., Bryn, P., 2004. Slope failure dynamics and impacts from seafloor and shallow sub-seafloor geophysical data: case studies from the COSTA project. Marine Geolology 213, 9-72.

Chamot-Rooke, N., Fournier, M., Scientific Team of AOC and OWEN cruises, 2009. Tracking Arabia-India motion from Miocene to Present, American Geophysical Union, Fall Meeting 2009.

Chaytor, J. D., Ten Brink, U.S., Solow, A. R., Andrews, B.D., 2009. Size distribution of submarine landslides along the U.S. Atlantic margin. Marine Geology 264, 16-27. 
Clemens, S.C., Prell, W.L., 2006. Viewpoint: The timing of orbital-scale Indian monsoon changes. Quaternary Science Reviews 25, 658-662.

Clift, P. D., Shimizu, N., Layne, G. D., Blusztain, J. S., Gaedicke, C., Schluter, H.-U., Clark, M. K., Amjad, S., 2001. Development of the Indus Fan and its significance for the erosional history of the Western Himalaya and Karakoram. Geological Society of America Bulletin 113(8), 1039-1051.

Corregiari, A., Trincardi, F., Langone, L., Roveri M., 2001. Styles of failure in late Holocene highstand prodelta wedges on the Adriatic shelf. Journal of Sedimentary Research 71, 218 236.

Dan, G., Sultan, N., Cattaneo, A., Deverchere J.,, Yelles K., 2010. Mass-transport deposits on the Algerian Margin (Algiers Area): Morphology, Lithology and Sedimentary Processes, Advances in Natural and Technological Hazards Research, in: "Submarine Mass Movements and Their Consequences", Mosher DC., Ship C., Moscardelli L., Chaytor J., Baxter C., Lee H. \& Urgeles R. (Eds.), 28, 527-539.

DeMets C., R. G. Gordon and D.F. Argus (2010), Geologically current plate motions, Geophysical Journal International, 181, 1-80, doi: 10.1111/j.1365-246X.2009.04491.x,.

Dingle, R.V., 1977. The anatomy of a large submarine slump on a sheared continental margin (SE Africa). Journal of the Geological Society of London 134 (3), 293-310.

Edwards, R.A., Minshull T.A., White, R.S., 2000. Extension across the Indian-Arabian plate boundary: the Murray Ridge. Journal Geophysical International 142, 461-477.

Edwards, R. A., Minshull, T. A., Flueh, E. R., Kopp, C., 2008. Dalrymple Trough: An active oblique-slip ocean-continent boundary in the northwest Indian Ocean. Earth and Planetary Science Letters 272, 437-445. 
Engdahl, E.R., van der Hilst, R., Buland, R., 1998. Global teleseismic earthquake relocation with improved travel times and procedures for depth determination. Bulletin of the Seismological Society of America 88, 722-743.

Faugères J.C., Gonthier E., Mulder T., Kenyon N., Cirac P., Griboulard R., Berné S., Lesuavé, R., 2002. Multi-process generated sediment waves on the Landes Plateau (Bay of Biscay, North Atlantic) Marine Geology 182, 279-302.

Field, M. E., Barber, J. H., 1993. A submarine landslide associated with shallow seafloor gas and gas hydrates off northern California, in Submarine landslides: selected studies in the U.S. Exclusive Economic Zone, W.C. Schwab et al (eds), US Geological Survey Bulletin, $2002,151-157$.

Fournier, M., Patriat, P., Leroy, S., 2001. Reappraisal of the Arabia-India-Somalia triple junction kinematics. Earth and Planetary Science Letters 189, 103-114.

Fournier, M., Chamot-Rooke, N., Petit, C., Fabbri, O., Huchon, P., Maillot, B., Lepvrier, C., 2008a. In-situ evidence for dextral active motion at the Arabia-India plate boundary. Nature Geoscience 1, 54-58, doi:10.1038/ngeo.2007.24.

Fournier, M., Petit, C., Chamot-Rooke, N., Fabbri, O., Huchon, P., Maillot, B., Lepvrier, C., 2008b. Do ridge-ridge-fault triple junctions exist on Earth? Evidence from the AdenOwen-Carlsberg junction in the NW Indian Ocean. Basin Research 20, 575-590, doi: 10.1111/j.1365-2117.2008.00356.x.

Fournier, M., Chamot-Rooke, N., Petit, C., Huchon, P., Al-Kathiri, A., Audin, L., Beslier, M.-O., d'Acremont, E., Fabbri, O., Fleury, J.-M., Khanbari, K., Lepvrier, C., Leroy, S., Maillot, B., Merkouriev, S., 2010. Arabia-Somalia plate kinematics, evolution of the AdenOwen-Carlsberg triple junction, and opening of the Gulf of Aden. Journal of Geophysical Research 115, B04102, doi:10.1029/2008JB006257. 
Fournier, M., Chamot-Rooke, N., Rodriguez, M., Huchon, P., Petit, C., Beslier, M.-O., Zaragosi, S., 2011. Owen Fracture Zone: the Arabia-India plate boundary unveiled. Earth and Planetary Science Letters302, 247-252, doi:10.1016/j.eps1.2010.12.027.

Gaedicke, C., Prexl, A., Schlüter, H.-U., Roeser, H. , Clift, P. 2002. Seismic stratigraphy and correlation of major regional unconformities in the northern Arabina Sea. In: The Tectonic and Climatic Evolution of the Arabian Sea Region (Eds P. Clift, D. Kroon, C. Gaedicke and J. Craig), Geological Society of London, Special Publication, 195, 25-36.

Gardner, J.V., Prior D.B., Field, M.E. 1999. Humboldt slide: A large shear-dominated retrogressive slope failure. Marine Geology 154, 323-338.

Gonthier E., Faugères, J.C., Gervais A., Ercilla, G., Alonso, B., Baraza J. 2002. Quaternary sedimentation and origin of the Orinoco sediment wave field on the Demerara continental rise (NE margin of South Amercia). Marine Geology 192, 189-214.

Gordon, R.G., DeMets, C. 1989. Present-day motion along the Owen fracture zone and Dalrymple trough in the Arabian Sea. Journal of Geophysical Research 94, 5560-5570.

Hampton, M.A., Lee, H.J., Locat, J., 1996. Submarine landslides. Review of Geophysics 34, 33-59.

Kvalstad T.J., Andresen, L., Forsberg, C.F., Kjell Berg, K., Bryn, P., Wangen, M., 2005. The Storegga slide: evaluation of triggering sources and slide mechanics; Marine and Petroleum Geology 22, 245-256.

Kristoffersen, Y., Coakley, B.J., Hall, J.K., Edwards, M., 2007. Mass wasting on the submarine Lomonosov Ridge, central Arctic Ocean. Marine Geology 243, 132-142.

Lee, H., Edwards, B.D., Field, M. E., 1981. Geotechnical analysis of a submarine slump, Eureka, California, paper presented at Offshore Technology Conference, American Association of Petroleum Geology, Houston, Tex. 
Lee, H.J., Syvitski, P.M., Parker, G., Orange, D., Locat, J., Hutton, J.H.W., Imran, J., 2002. Distinguishing sediment waves from slope failure deposits : Field examples, including the Humboldt slide and modelling results. Marine Geology 192, 79-104.

Lee, H. J., Locat, J., Desgagnes, P., Parsons, J.D., McAdoo, B.G., Orange, D.L., Puig, P., Wong, F.L., Dartnell, P., Boulanger, E., 2007. Submarine mass movements on continental margins, in Continental Margin Sedimentation, edited by C. A. Nittrouer, pp. 213-274, doi:10.1002/9781444304398.ch5, Blackwell, U. K.

Lonsdale, P., Fornari, D., 1980. Submarine geology of Malpelo ridge, Panama basin. Marine Geology 36, 65-83.

Massel, C., Coffin, M.F., Mann, P., Mosher, S., Frohlich, C., Duncan, C.S., Karner, G., Ramsay, D., Lebrun, J.-F., 2000. Neotectonics of the Macquarie Ridge Complex, Australia-Pacific plate boundary. Journal of Geophysical Research 105, 13457-13480.

Masson, D.G., Harbitz, C.B., Wynn, R.B., Pedersen, G., Løvholt, F., 2006. Submarine landslides: processes, triggers and hazard prediction. Philosophical Transaction of the Royal Society A. 364, 2009-2039.

McAdoo, B.G., Pratson, L.F., Orange, D.L. 2000. Submarine landslide morphology, US continental slope. Marinr geology 169, 103-136.

McAdoo B.G., Capone, M.K., Minder, J., 2004. Seafloor morphology of convergent margins: implications for Cascadia seismic hazard. Tectonics 23, TC 6008, doi: 10. 1029/2003TC001570.

Michaud, F., Chabert, A., Collot, J.-Y, Sallarès, V., Flueh, E.R., Charvis, P., Graindorge, D., Gustcher, M.A., Bialas, J., 2005. Fields of multi-kilometer scale sub-circular depressions in the Carnegie Ridge sedimentary blanket: Effect of underwater carbonate dissolution? Marine Geology 216, 205-219. 
Mienert, J., Posewang, J., 1999. Evidence of shallow- and deep-water gas hydrate destabilizations in North Atlantic polar continental margin sediments. Geo-marine letters $19,143-149$.

Mouchot, N., 2009. Tectonique et sédimentation sur le complexe de subduction du Makran pakistanais. Unpublished $\mathrm{PhD}$ thesis, Cergy Univ., France, 364 pp.

Mountain, G.S., Prell, W.L., 1989. Geophysical Reconnaissance Survey for ODP Leg 117 in the Northwest Indian Ocean. In: Proc. ODP, Init. Repts. (Ocean Drilling Program) (Eds W.L. Prell and N. Niitsuma), 117, pp. 51-64, College Station, TX.

Mountain, G. S., Prell, W.L. 1990. A multiphase plate tectonic history of the southeast continental margin of Oman. In: Robertson, A. H. F., Searle, M. P. and Ries, A. C. (eds) the Geology and Tectonics of the Oman Region, Geological Society of London Special Publications, 49, 725-743.

Mulder, T., Cochonat, P., 1996. Classification of offshore mass movements. Journal of Sedimentary Research. 66, 43-57.

Mulder, T., Alexander, J., 2002. Abrupt change in slope causes variation in the deposit thickness of concentrated particle-driven density currents, Marine Geology, 175, 221-235.

Mulder, T., Gonthier, E., Lecroart, P., Hanquiez, V., Marches, E., Voisset, M., 2009. Sediment failures and flows in the Gulf of Cadiz (western Atlantic). Marine and Petroleum Geology, Spec. Issue, V. Gaullier et Vendeville (eds), 26, 660-672.

Pimm, A. C., Burroughs, R. H., Bunce, E.T. 1972. Oligocene sediments near Chain Ridge, northwest Indian Ocean: structural implications. Marine Geology 13, 14-18.

Piper, D.J.W., Cochonat, P., Morrison, M., 1999. The sequence of events around the epicenter of the 1929 Grand Bank earthquake: initiation of debris flows and turbidity current inferred from sidescan sonar. Sedimentology, 46, 79-97. 
Prior, D.B., Coleman, J., 1980. Sonograph mosaics of submarine slope instabilities, Mississippi River delta. Marine Geology, 36, 226-239.

Prior, D.B., 1999. Sea floor engineering geomorphology: recent achievements and future directions. Geomorphology 31, 411-439.

Quittmeyer, R. C., Kafka, A. L., 1984. Constraints on plate motions in southern Pakistan and the northern Arabian Sea from the focal mechanisms of small earthquakes. Journal of Geophysical Research 89, 2444-2458.

Robinson, D. P., 2011. A rare great earthquake on a oceanic fossil fracture zone. Geophysical Journal International, 186, 1121-1134. doi:10.1111/j.1365246X.2011.05092.x

Rodriguez, M., Fournier, M., Chamot-Rooke, N., Huchon, P., Bourget, J., Sorbier, M., Zaragosi, S., Rabaute, A., 2011. Neotectonics of the Owen Fracture Zone (NW Indian Ocean): structural evolution of an oceanic strike-slip plate boundary (2011). Geochemistry, Geophysics, Geosystems, 12, Q12006, doi:10.1029/2011GC003731.

D.J. Shillington, Seeber, L., Sorlien, C.C., Steckler, M. S., Kurt, H., Dondurur, D., Çifçi, G., İmren, C., Cormier, M. H., McHugh, C.M.G., Gürçay, S., Poyraz, D., Okay, S., Atgın, O., Diebold J.B., 2012. Evidence of widespread creep on the flanks of the Sea of Marmara transform basin from marine geophysical data. Geology 40, 439-442, doi:10.1130/G32652.1

Shipboard Scientific Party, Site 222 (1974), in DSDP Init. Repts, leg 23, edited by R.B. Whitmarsh, O.E. Weser and D.A. Ross, doi:10.2973/dsdp.proc.23.106.

Shipboard Scientific Party, 1989. Site 731. In Prell, W.L., Niitsuma, N., et al., Proc. ODP, Init. Repts., 117: College Station, TX (Ocean Drilling Program), 585-652.

Strozyk, F., Strasser, M., Krastel, S., Meyer, M., Huhn, K., 2010. Reconstruction of retreating mass wasting in response to progressive slope steepening of the northeastern Cretan margin, eastern Mediterranean. Marine Geology 271, 44-54. 
Sultan, N., Cattaneo, A., Urgeles, R., Lee, H., Locat, J., Trincardi, F., Berne, S., Canals, M., Lafuerza, S., 2008. A geomechanical approach for the genesis of sediment undulations on the Adriatic shelf. Geochemistry, Geophysics, Geosystems 9, Q04R03, doi: 10.1029/2007GC001822.

Tappin, D.R., McNeil, L.C., Henstock, T., Mosher, D., 2007. Mass wasting processes offshore Sumatra. V. Lykousis, D. Sakellariou and J. Locat (eds.), Submarine Mass Movements and Their Consequences 327-336.

Tripsanas, E.K., Piper, D.J.W., Jenner, K.A., Bryant, W.R., 2008. Submarine mass-transport facies: new perspectives on flow processes from cores on the eastern North American margin. Sedimentology 55, 97-136.

Twichell, D.C., Chaytor, J.D., ten Brink, U.S., Buczkowski, B., 2009. Morphology of late Quaternary submarine landslides along the U.S. Atlantic continental margin. Marine Geology 264, 4-15.

Viesca, R.C., J. Rice, 2012. Nucleation of sleep-weakening rupture instability in landslides by localized increase in pore pressure. Journal of Geophysical Research, 117, B03104, doi:10.1029/2011JB008866

Völker, D., Scholz, F., Geersen, J., 2011. Analysis of submarine landsliding in the rupture area of the 27 February 2010 Maule earthquake, Central Chile. Marine Geology 288, 7989.

Weissel, J.K., Childers, V.A., Karner, G.D., 1992. Extensional and Compressional Deformation of the Lithosphere in the Light of ODP Drilling in the Indian Ocean. Synthesis of Results from Scientific Drilling in the Indian Ocean, Geophysical Monography 70, American Geophysical Union. 
Whitmarsh, R.B., 1979. The Owen Basin off the south-east margin of Arabia and the evolution of the Owen Fracture Zone. Geophysical Journal of the Royal Astronomical Society $58,441-470$.

Whitmarsh, R.B., Weser, O. E., Ross, D. A., 1974. Initial report DSDP, U.S. Government Printing Office, Washington, D.C., v. 23, p. 1180. 


\section{Highlights:}

_Discovery of large submarine failures (up to $40 \mathrm{~km}^{3}$ in volume) along the Owen Ridge (Arabian Sea)

_A large diversity of slope failure morphologies

_A rare description of mass wasting processes in a pelagic context

_Mass wasting frequency does not fit large $(\mathrm{Mw}>7)$ earthquake frequency and is restricted by slow pelagic rates 
$17^{\circ} 20^{\prime} \mathrm{N}$ Landslide
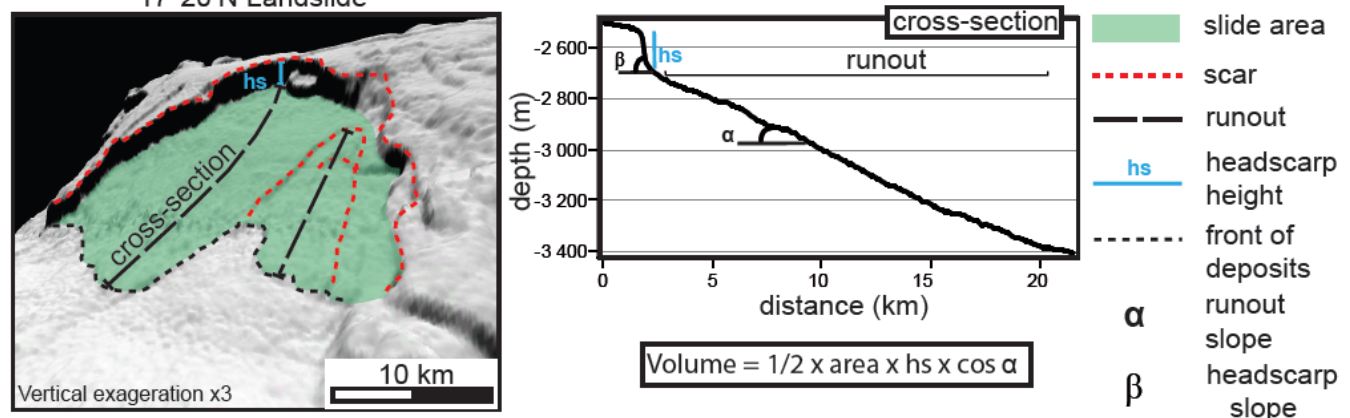

\begin{tabular}{|c|c|c|c|c|c|c|c|}
\hline $\begin{array}{l}\text { correlations (covariance) } \\
\text { Southern ridge } \\
\text { (western slope) }\end{array}$ & area & $\begin{array}{l}\text { water depth } \\
\text { of failure initiation }\end{array}$ & $\begin{array}{l}\text { headscarp } \\
\text { height }\end{array}$ & $\begin{array}{l}\text { scar } \\
\text { length }\end{array}$ & $\begin{array}{l}\text { headscarp } \\
\text { slope }\end{array}$ & $\begin{array}{l}\text { runout } \\
\text { slope }\end{array}$ & volume \\
\hline area & 1 & & & & & & \\
\hline water depth of failure initiation & 0.10 & 1 & & & & & \\
\hline headscarp height & -0.02 & -0.32 & 1 & & & & \\
\hline scar length & 0.93 & 0.15 & 0.02 & 1 & & & \\
\hline headscarp slope & -0.19 & -0.34 & 0.19 & -0.25 & 1 & & \\
\hline runout slope & -0.17 & -0.18 & 0.37 & -0.16 & 0.39 & 1 & \\
\hline volume & 0.69 & -0.06 & 0.56 & 0.69 & -0.09 & 0.15 & 1 \\
\hline Central ridge & area & $\begin{array}{l}\text { water depth } \\
\text { of failure initiation }\end{array}$ & $\begin{array}{l}\text { headscarp } \\
\text { height }\end{array}$ & $\begin{array}{l}\text { scar } \\
\text { length }\end{array}$ & $\begin{array}{l}\text { headscarp } \\
\text { slope }\end{array}$ & $\begin{array}{l}\text { runout } \\
\text { slope }\end{array}$ & volume \\
\hline area & 1 & & & & & & \\
\hline water depth of failure initiation & -0.20 & 1 & & & & & \\
\hline headscarp height & 0.03 & -0.55 & 1 & & & & \\
\hline scar length & 0.87 & -0.12 & 0.01 & 1 & & & \\
\hline headscarp slope & -0.08 & -0.41 & 0.73 & -0.07 & 1 & & \\
\hline runout slope & -0.07 & 0.14 & -0.17 & 0.10 & 0.15 & 1 & \\
\hline volume & 0.89 & -0.41 & 0.29 & 0.70 & 0.09 & -0.10 & 1 \\
\hline Northern ridge & area & $\begin{array}{l}\text { water depth } \\
\text { of failure initiation }\end{array}$ & $\begin{array}{c}\text { headscarp } \\
\text { height }\end{array}$ & $\begin{array}{l}\text { scar } \\
\text { length }\end{array}$ & $\begin{array}{l}\text { headscarp } \\
\text { slope }\end{array}$ & $\begin{array}{l}\text { runout } \\
\text { slope }\end{array}$ & volume \\
\hline area & 1 & & & & & & \\
\hline water depth of failure initiation & 0.05 & 1 & & & & & \\
\hline headscarp height & -0.17 & -0.06 & 1 & & & & \\
\hline scar length & 0.94 & 0.03 & -0.10 & 1 & & & \\
\hline headscarp slope & -0.18 & 0.09 & 0.65 & -0.07 & 1 & & \\
\hline runout slope & -0.20 & -0.41 & -0.10 & -0.05 & 0.32 & 1 & \\
\hline volume & 0.66 & 0.13 & 0.25 & 0.78 & 0.37 & -0.08 & 1 \\
\hline
\end{tabular}

Table 1 


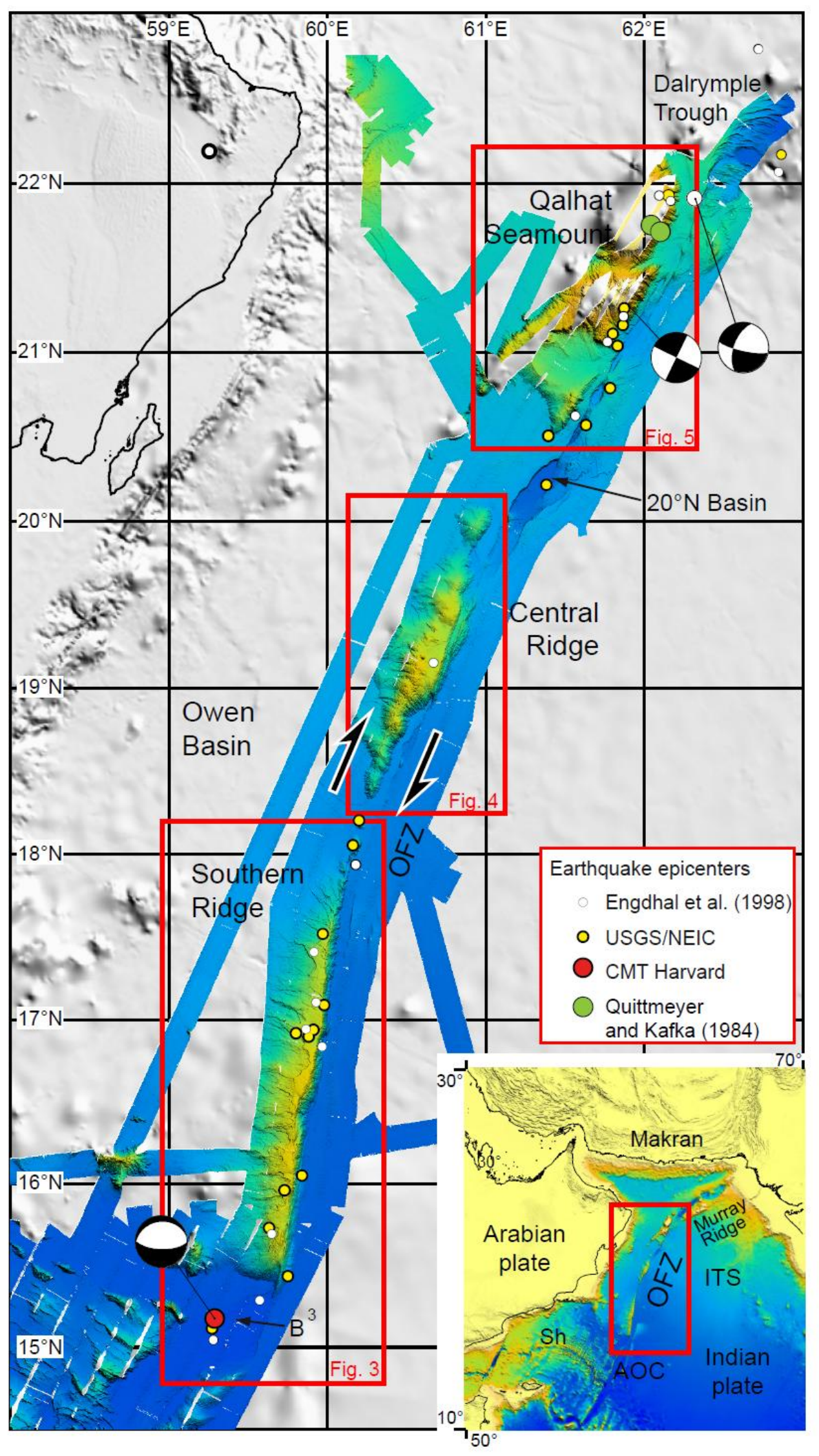

Figure 1 


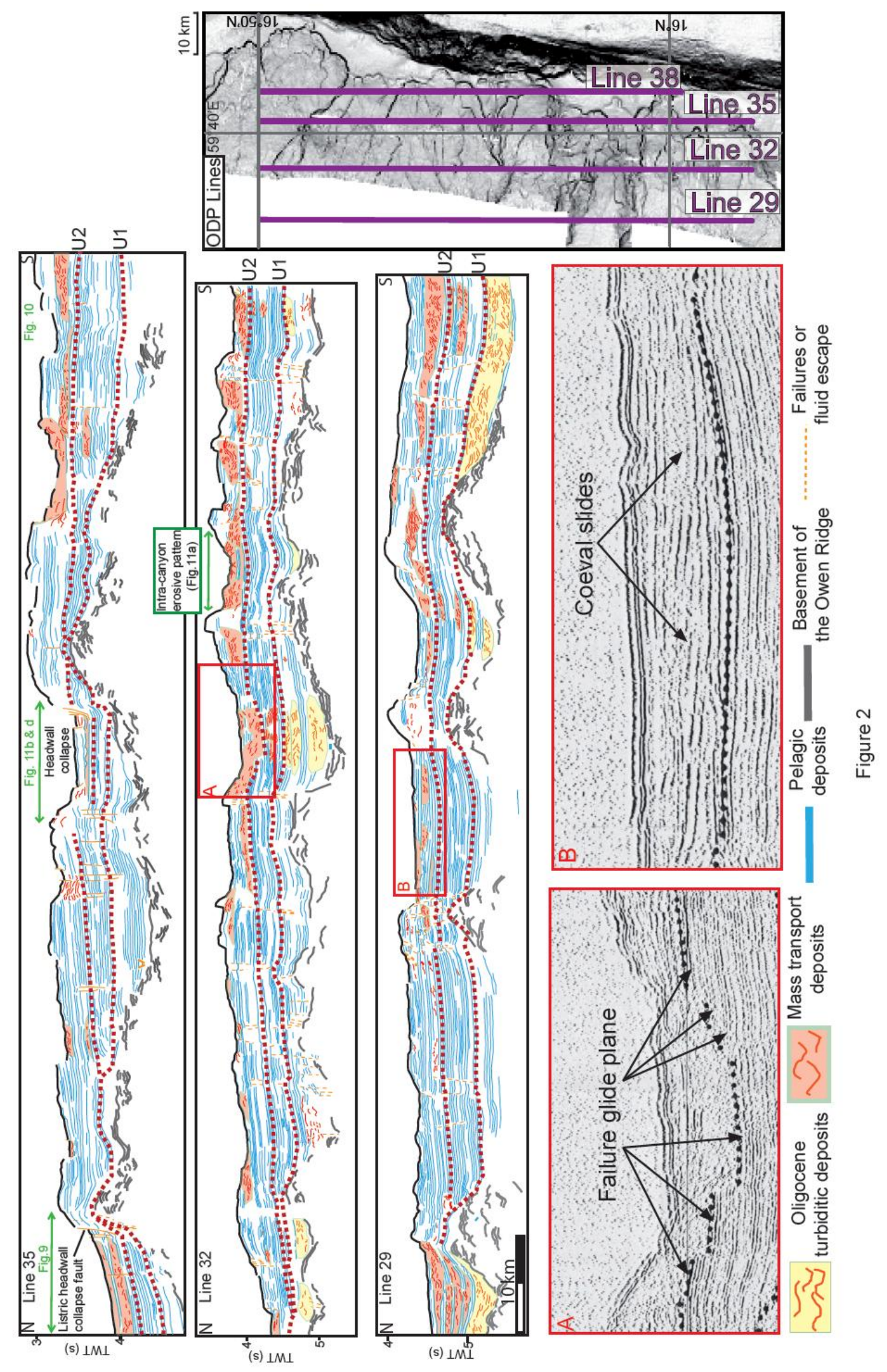



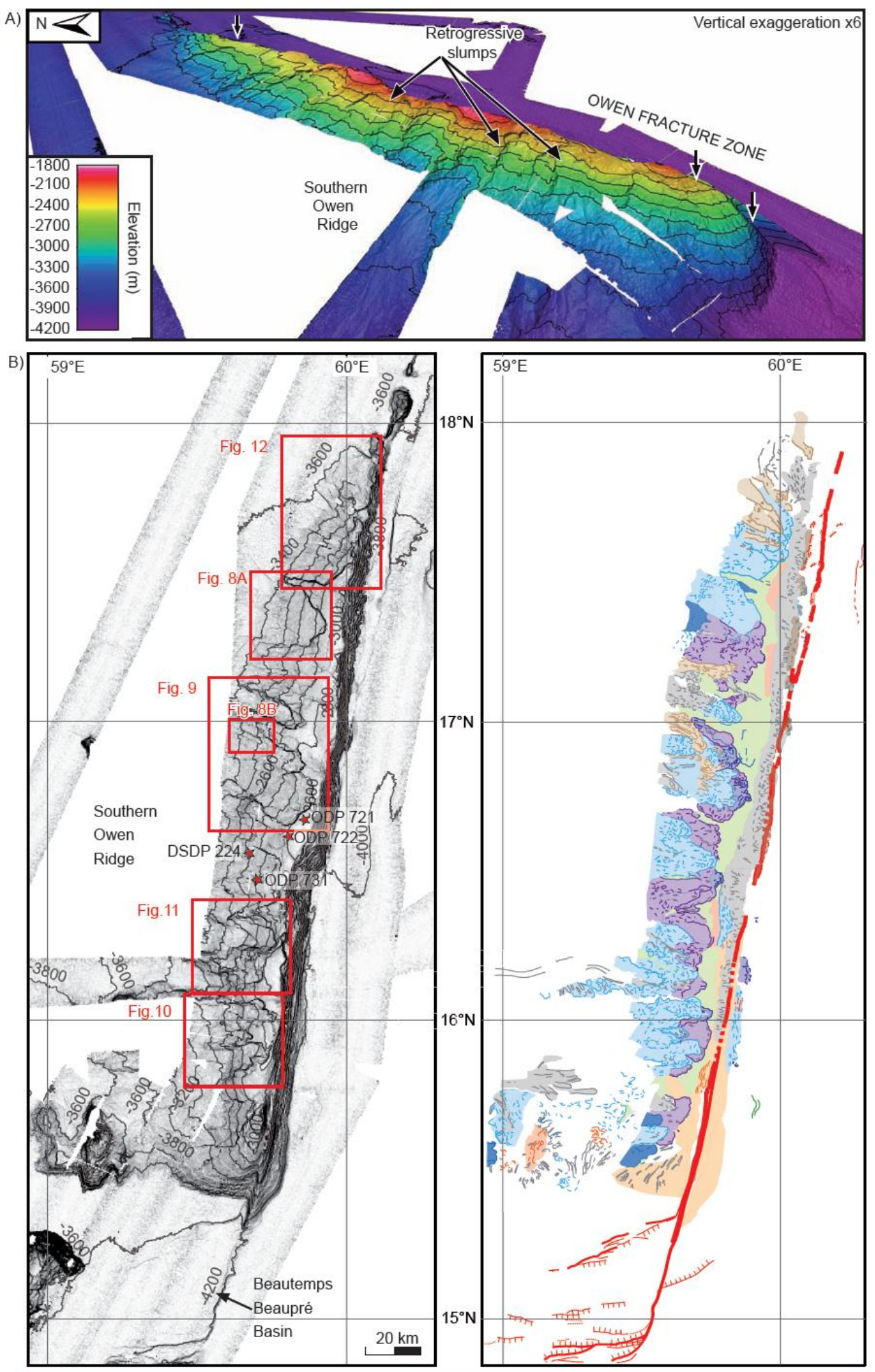

\begin{tabular}{|c|c|c|c|c|}
\hline \multirow{2}{*}{ +w } & \multirow{2}{*}{$\begin{array}{l}\text { Owen Fracture Zone } \\
\text { Normal faults }\end{array}$} & Mass wasting features: & \multirow[b]{2}{*}{ Cohesive slide } & \multirow{2}{*}{$\begin{array}{l}\text { Disintegrative } \\
\text { slide }\end{array}$} \\
\hline & & Stable area & & \\
\hline & Turbiditic channel & $\begin{array}{l}\text { Sub-circular } \\
\text { depressions }\end{array}$ & $\begin{array}{c}\text { Headwall } \\
\text { collapse area }\end{array}$ & Elongate scar \\
\hline & $\begin{array}{l}\text { Location of ODP } \\
\text { and DSDP sites }\end{array}$ & $\begin{array}{ll}\text { Undulating } \\
\text { seafloor }\end{array}$ & Glide blocks & $\begin{array}{l}\text { Gullies } \\
\text { Mass transport } \\
\text { deposits }\end{array}$ \\
\hline
\end{tabular}

Figure 3 


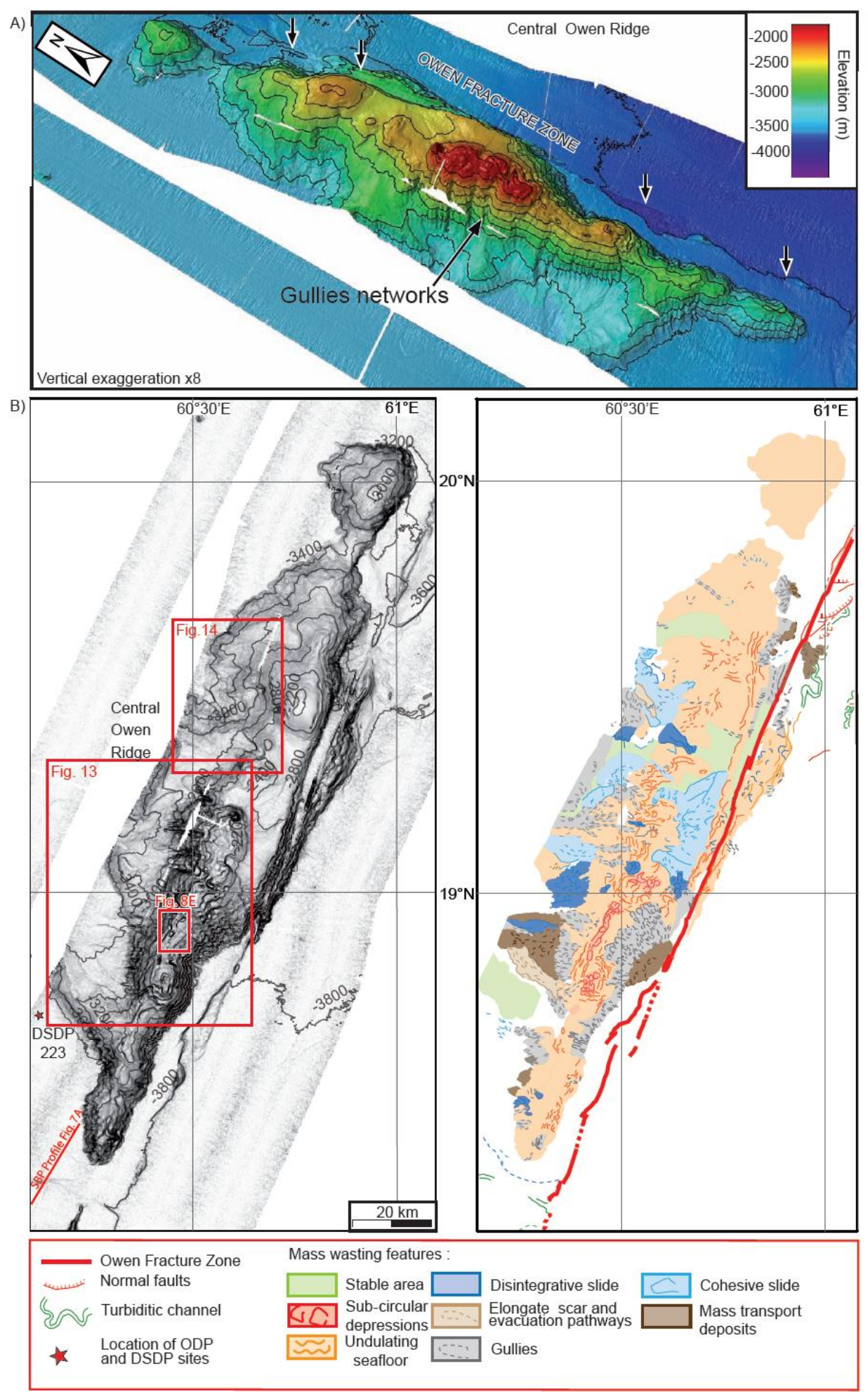

Figure 4 

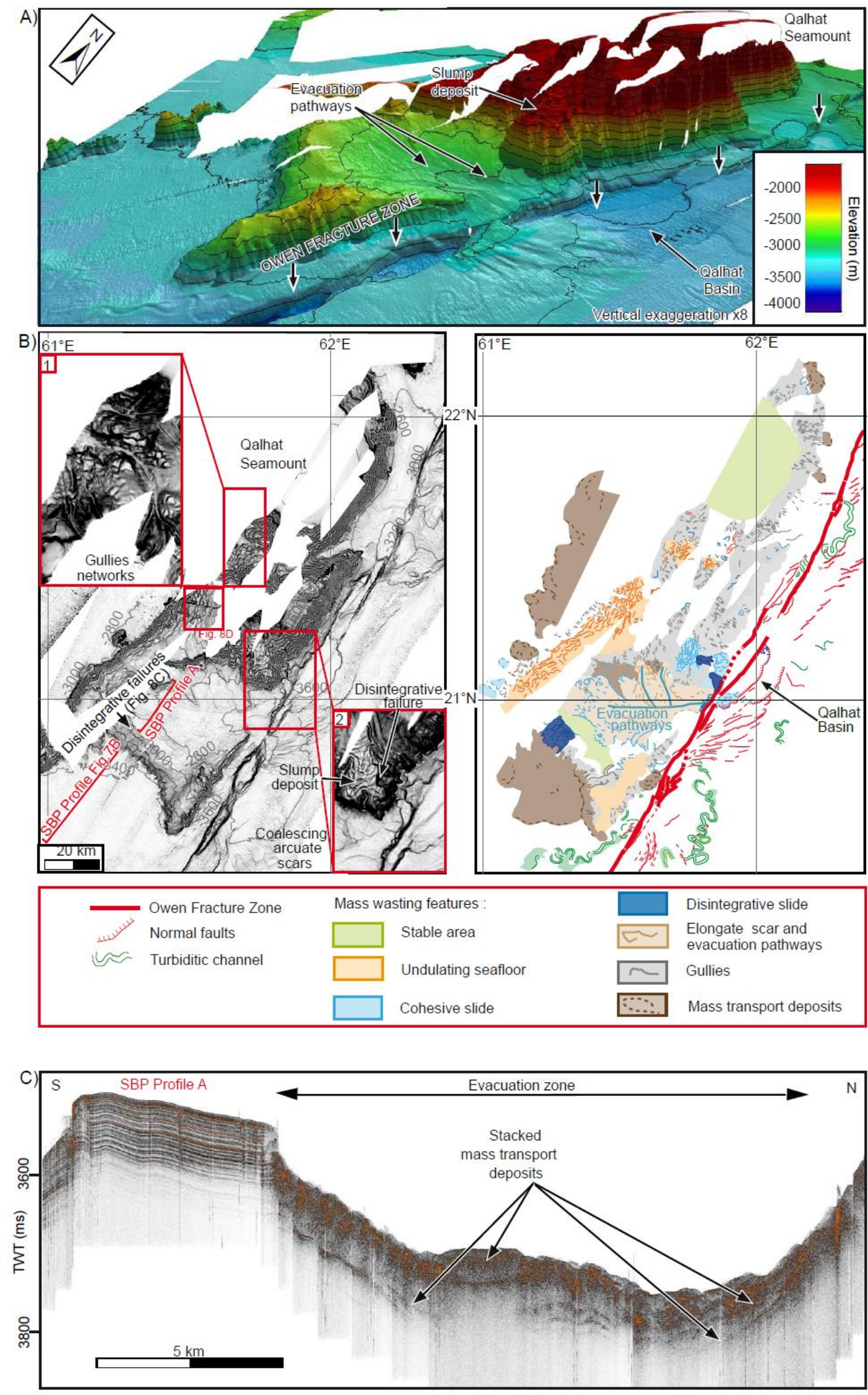

Figure 5 

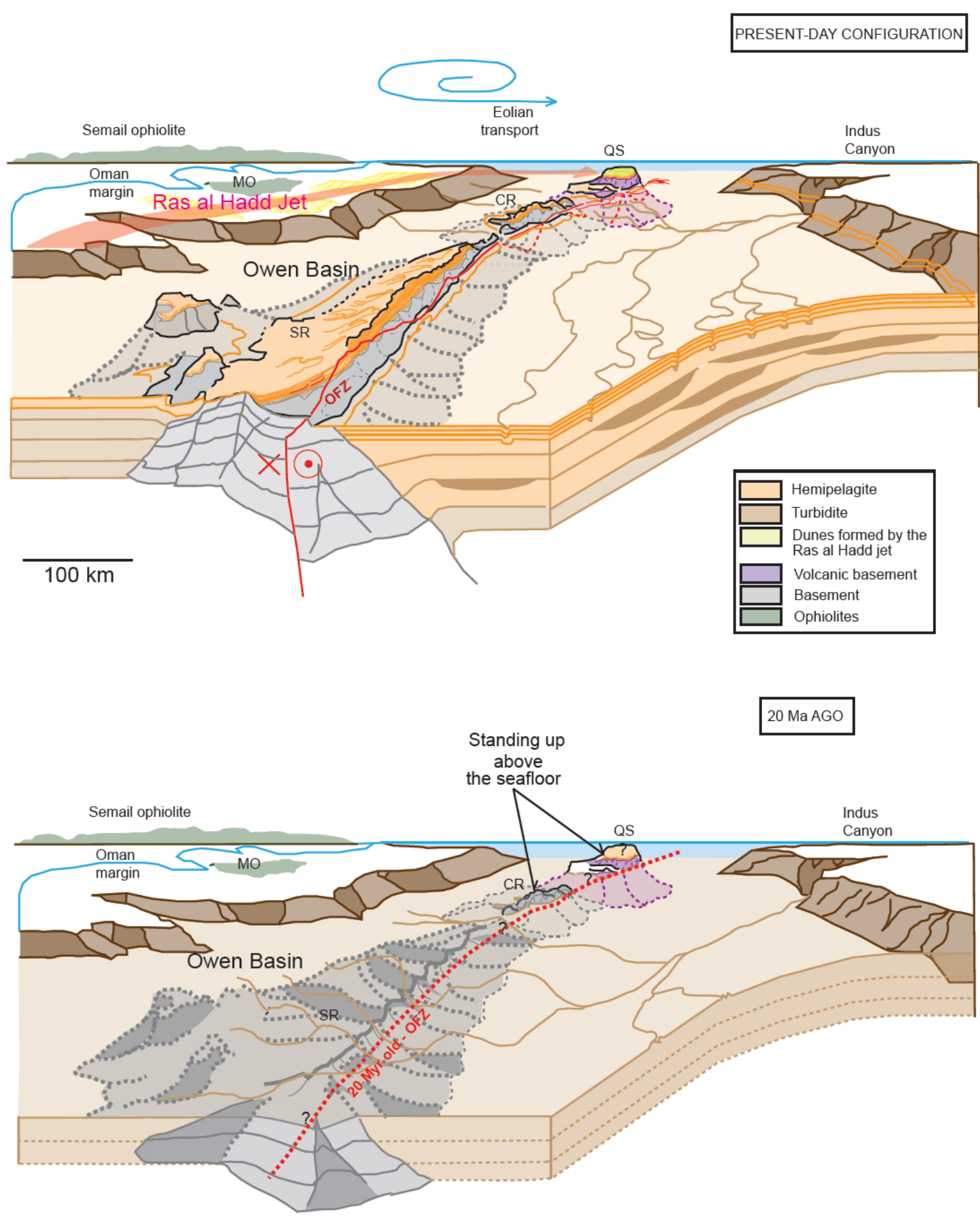

Figure 6 

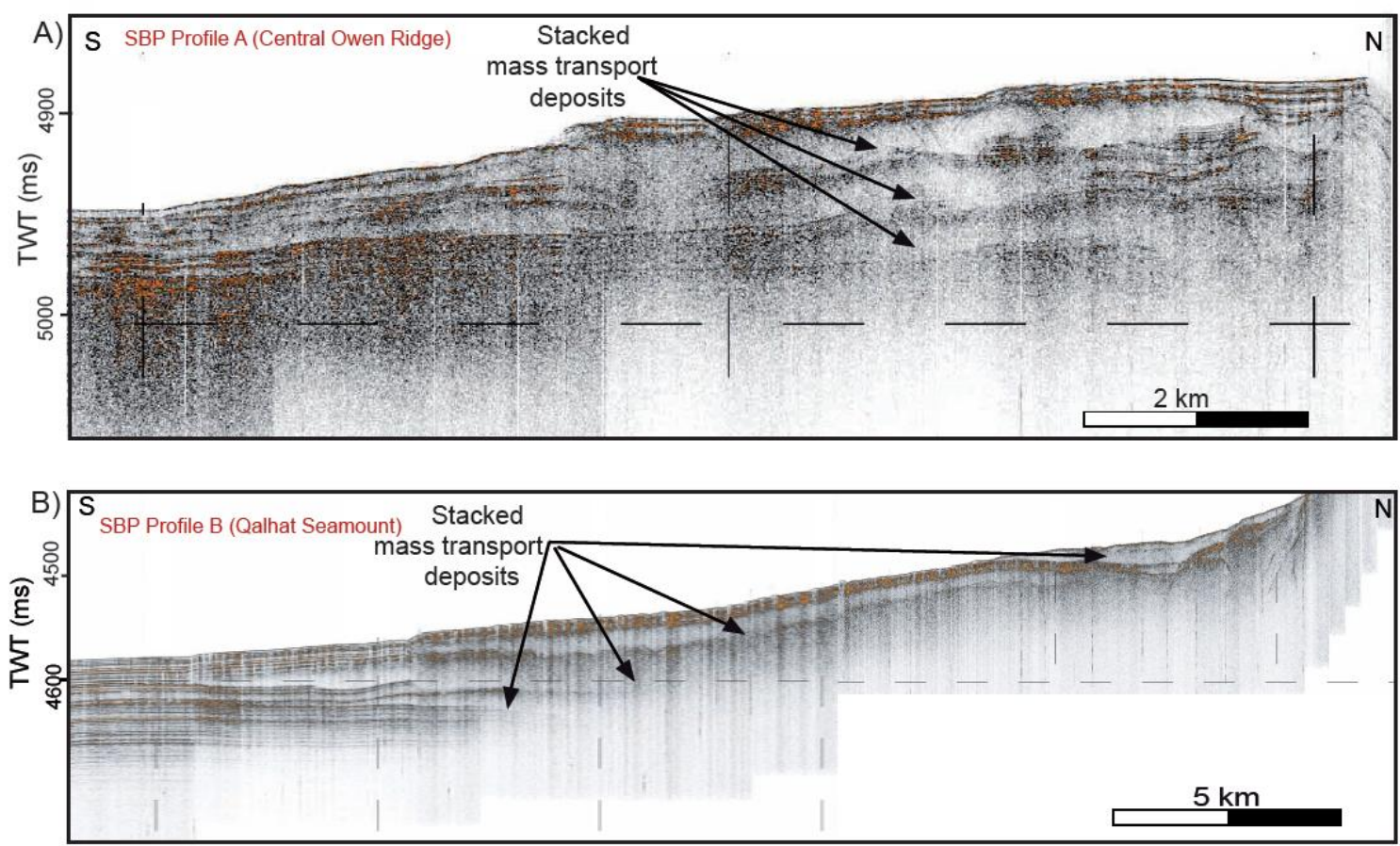

Figure 7 


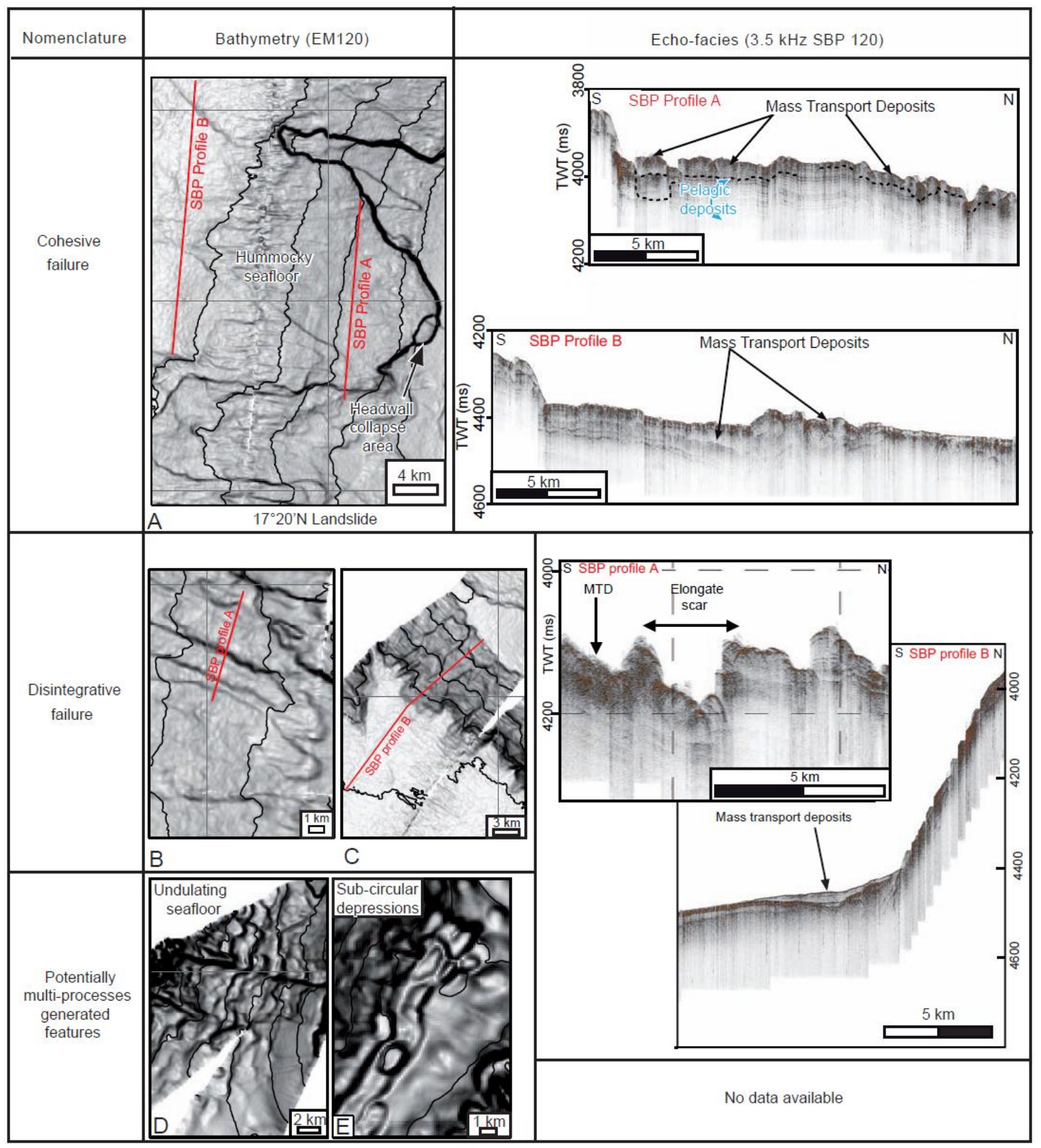

Figure 8 

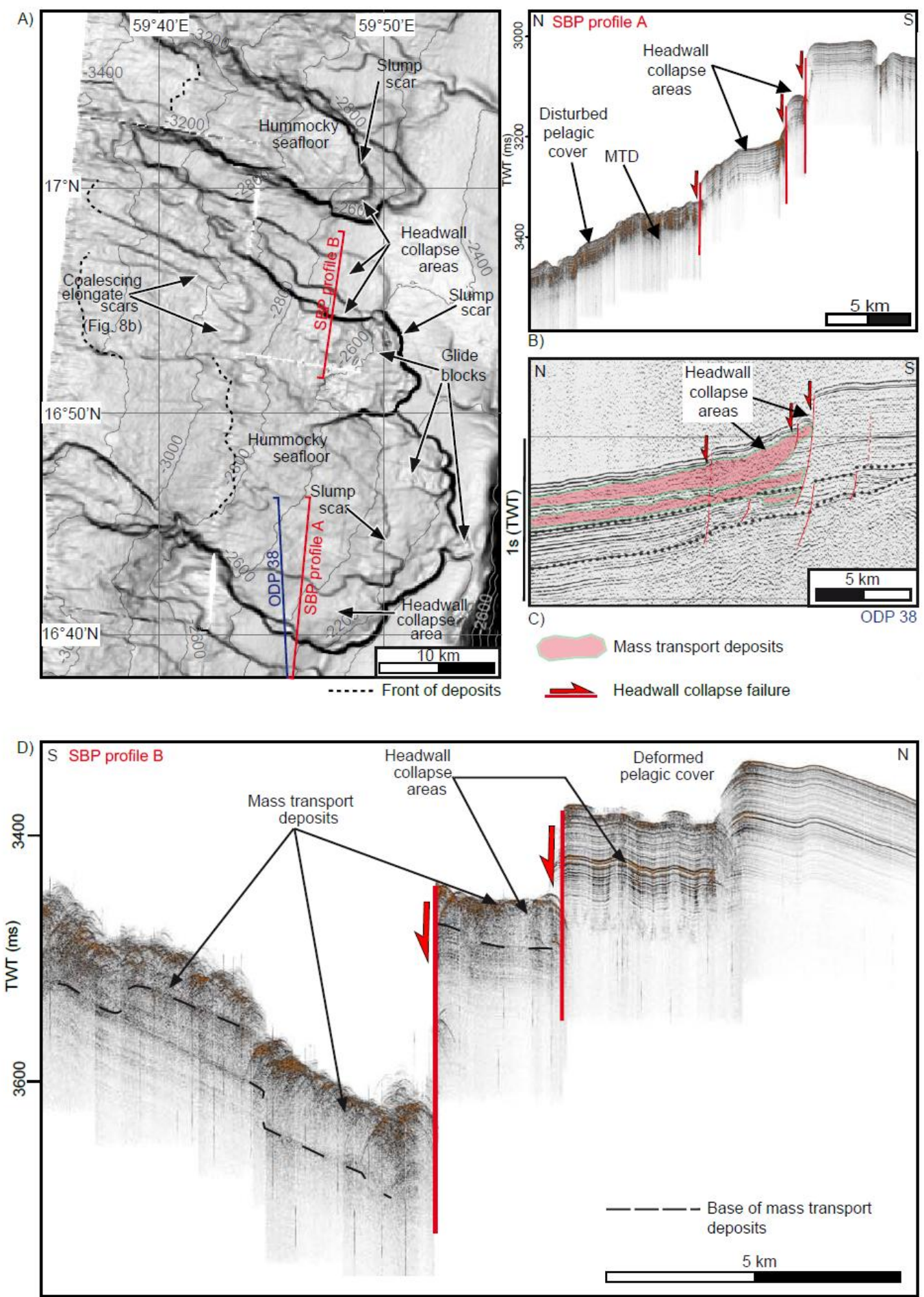

Figure 9 

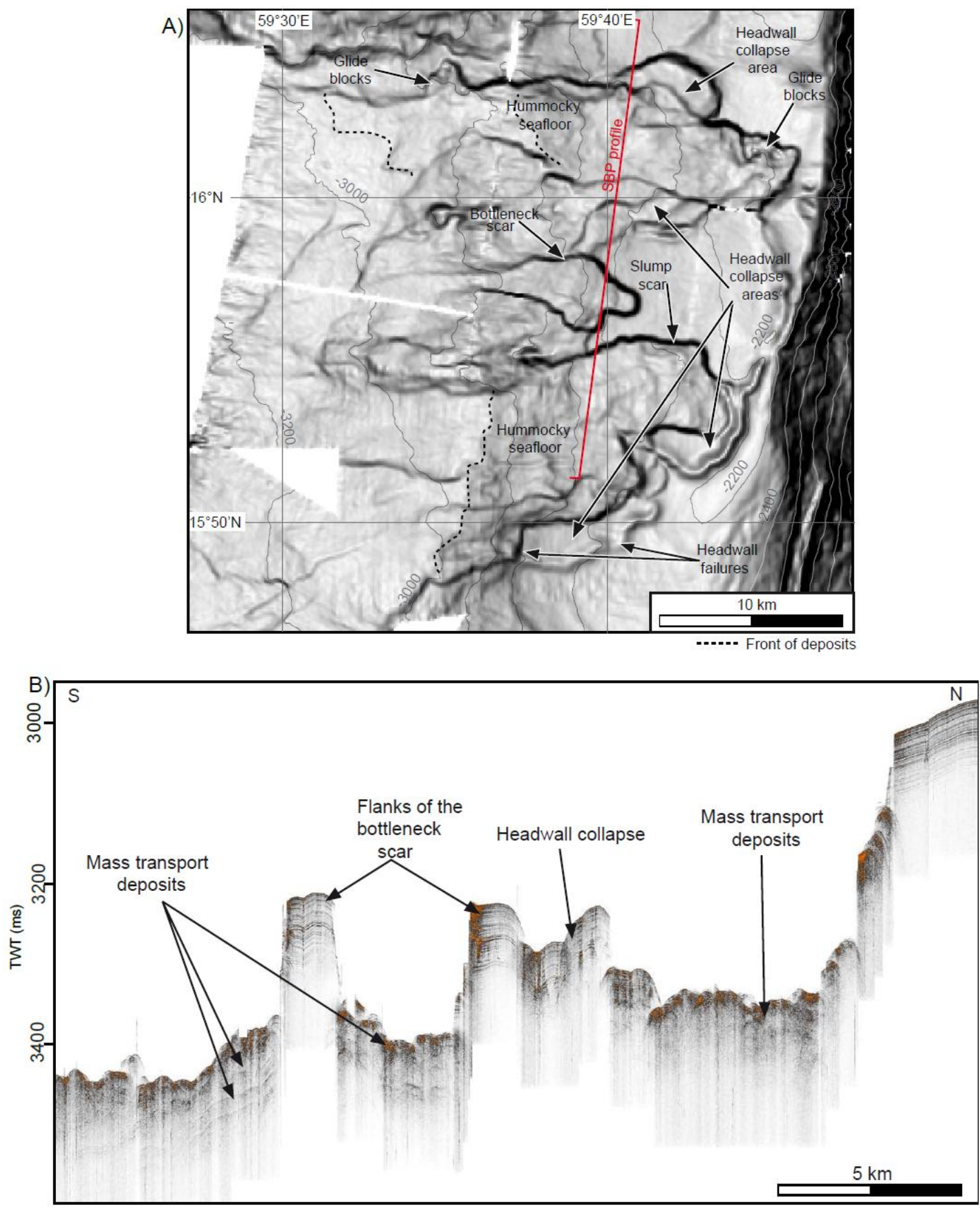

Figure 10 

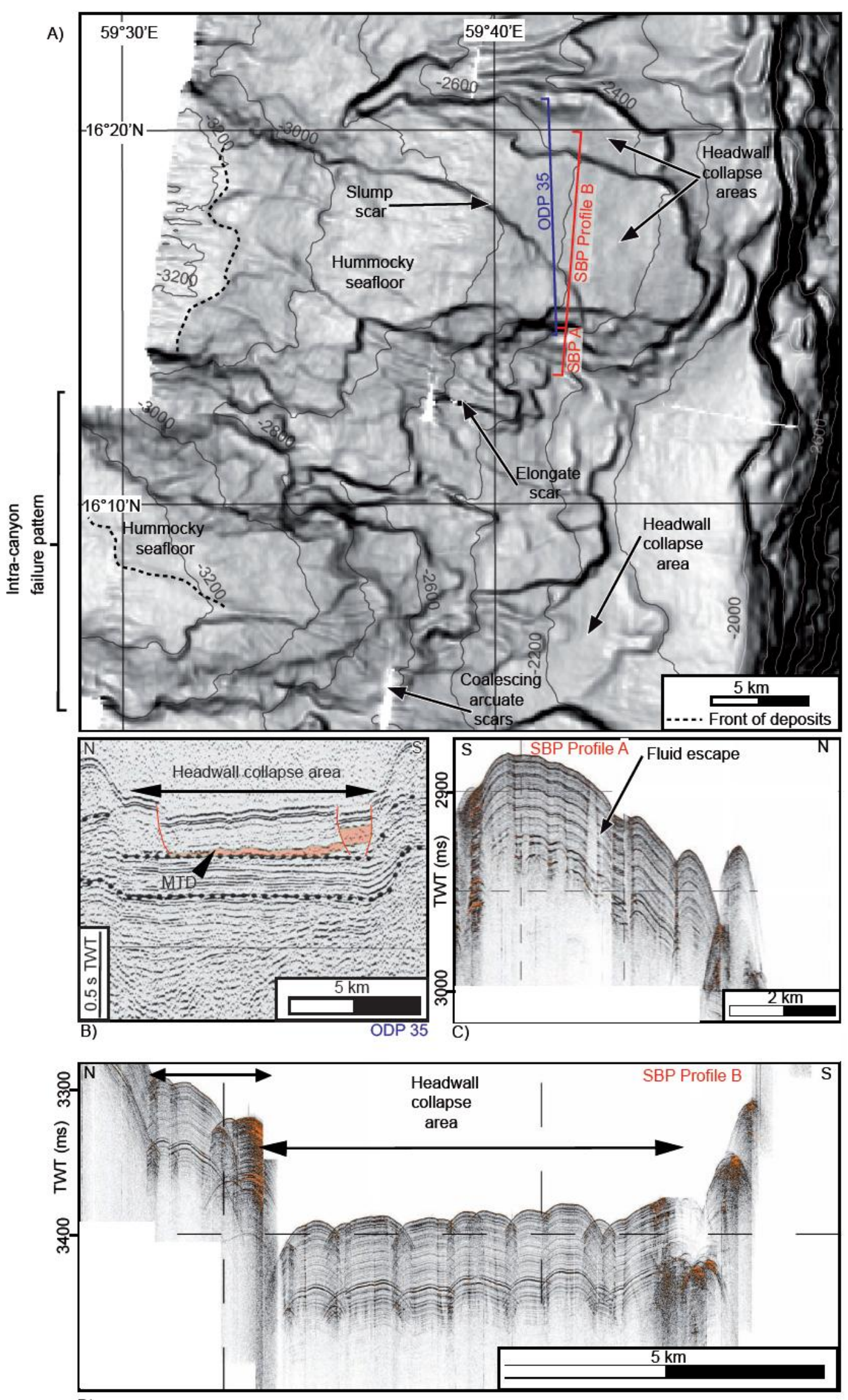

Figure 11 

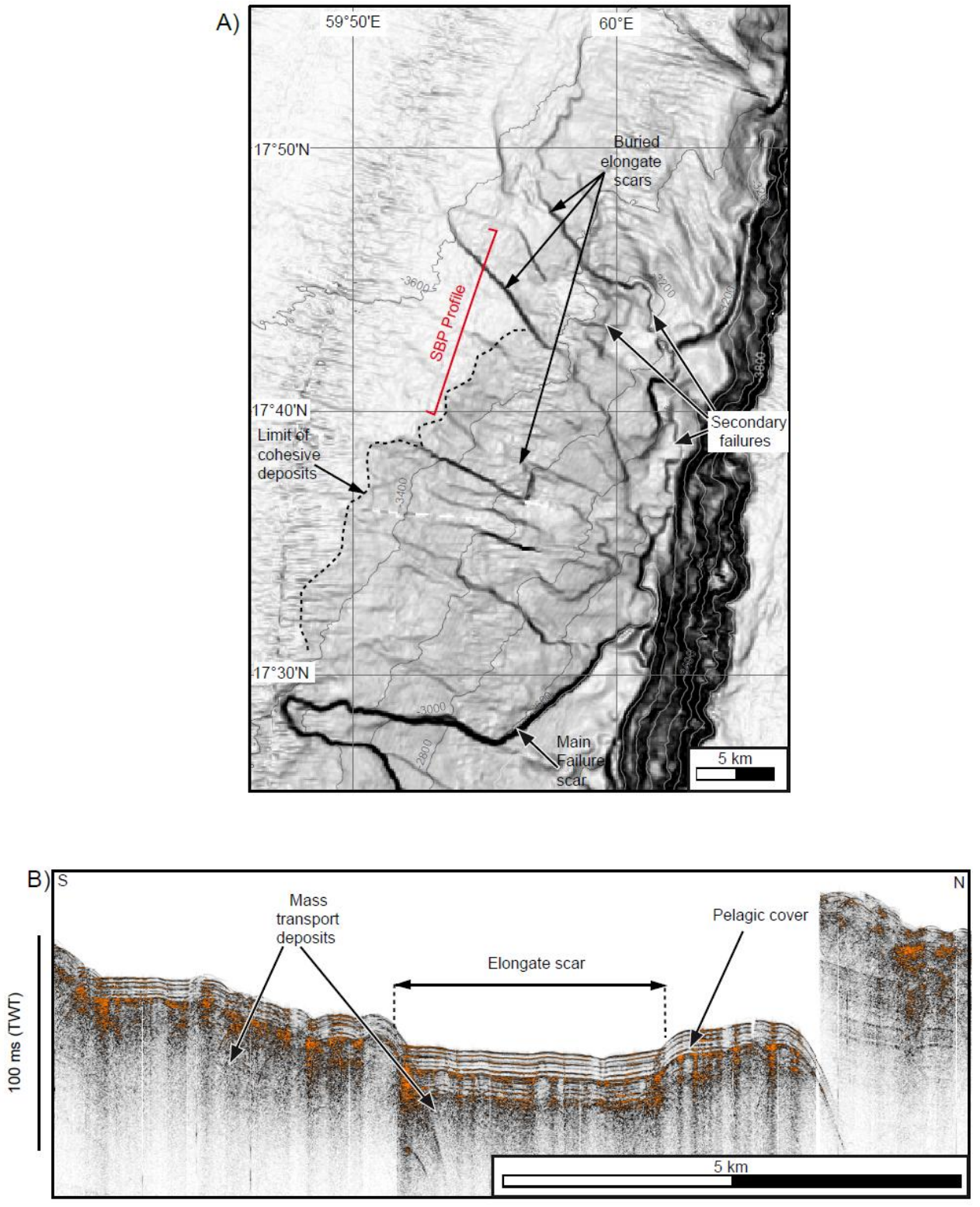

Figure 12 

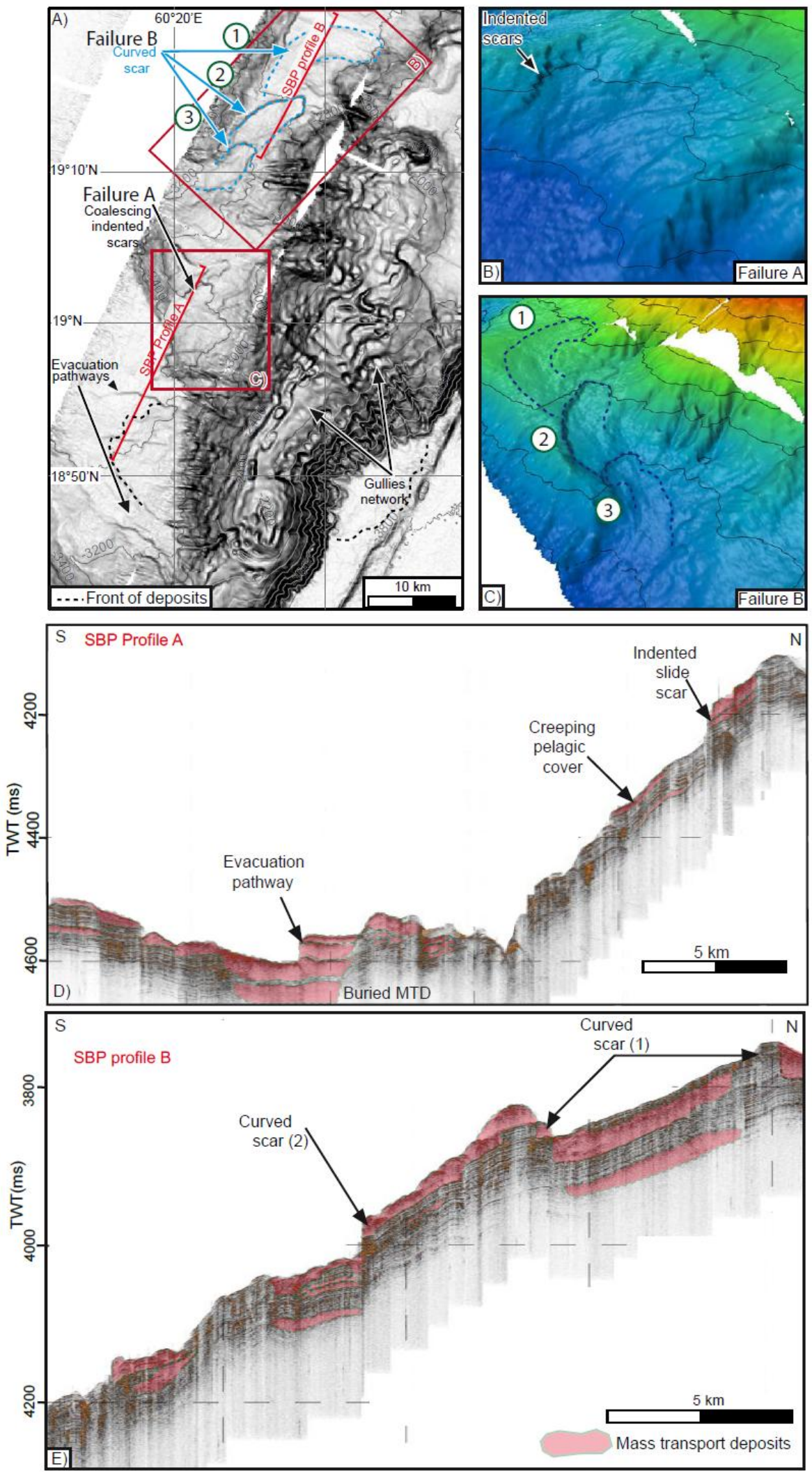

Figure 13 


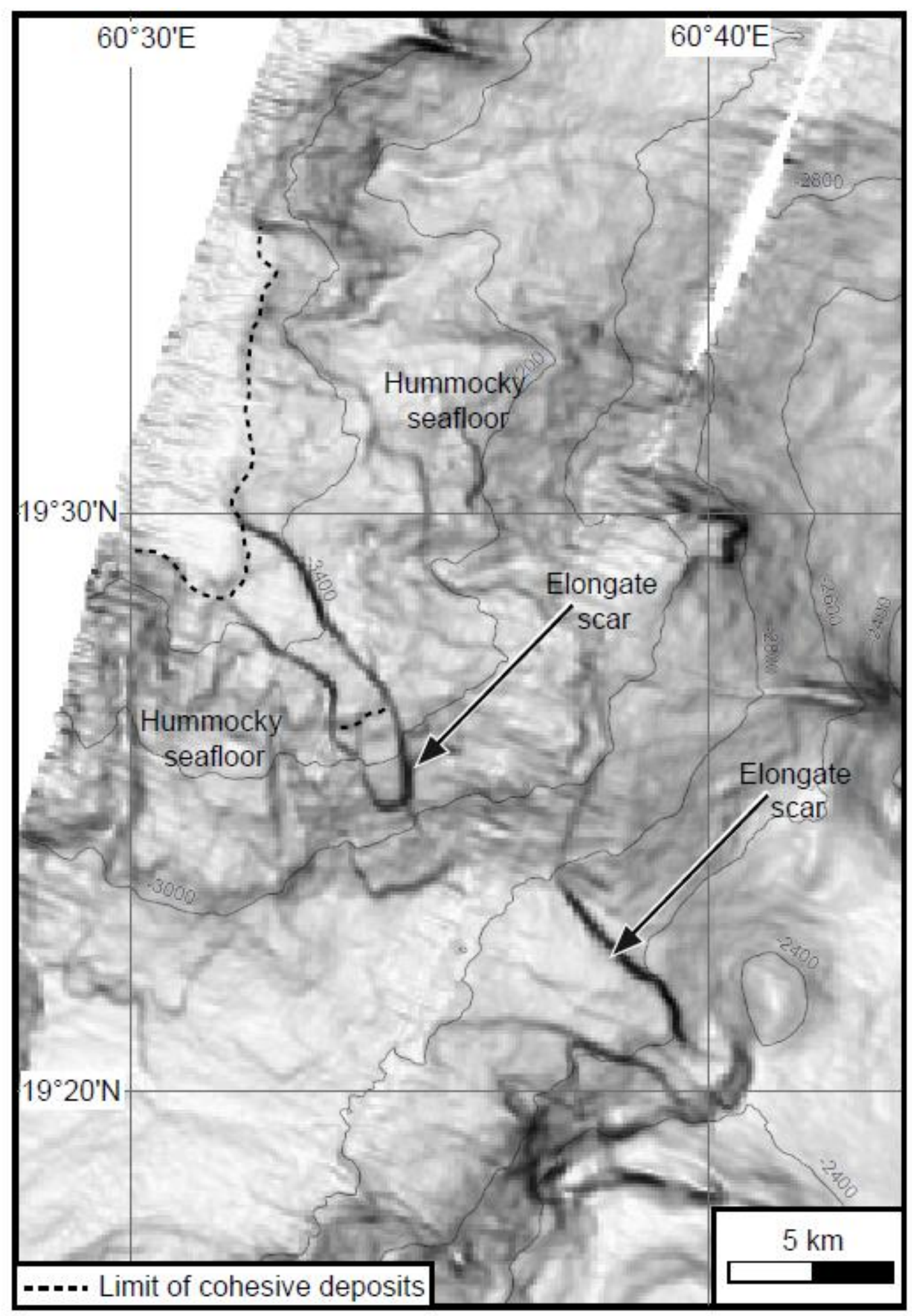

Figure 14 


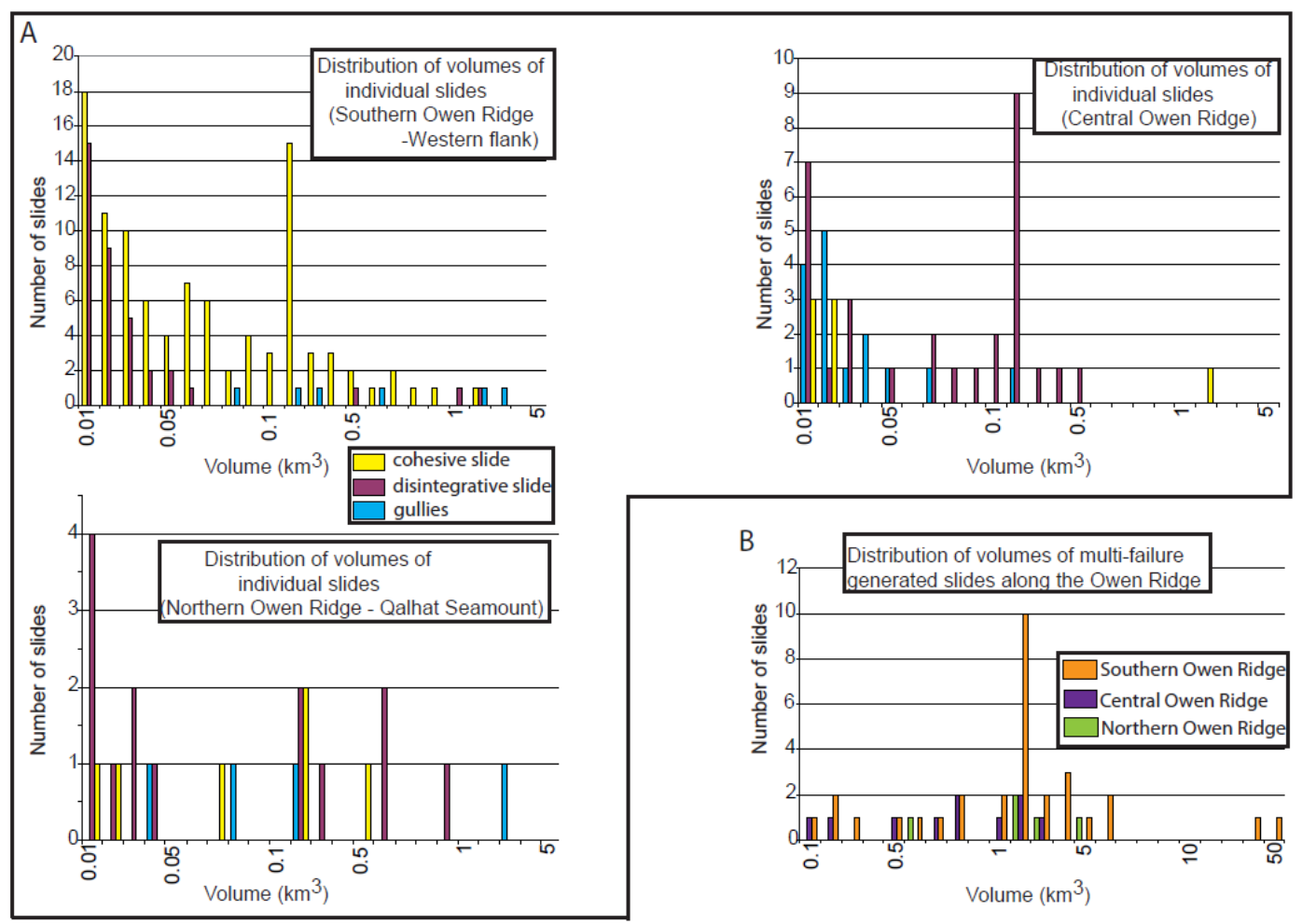

Figure 15 


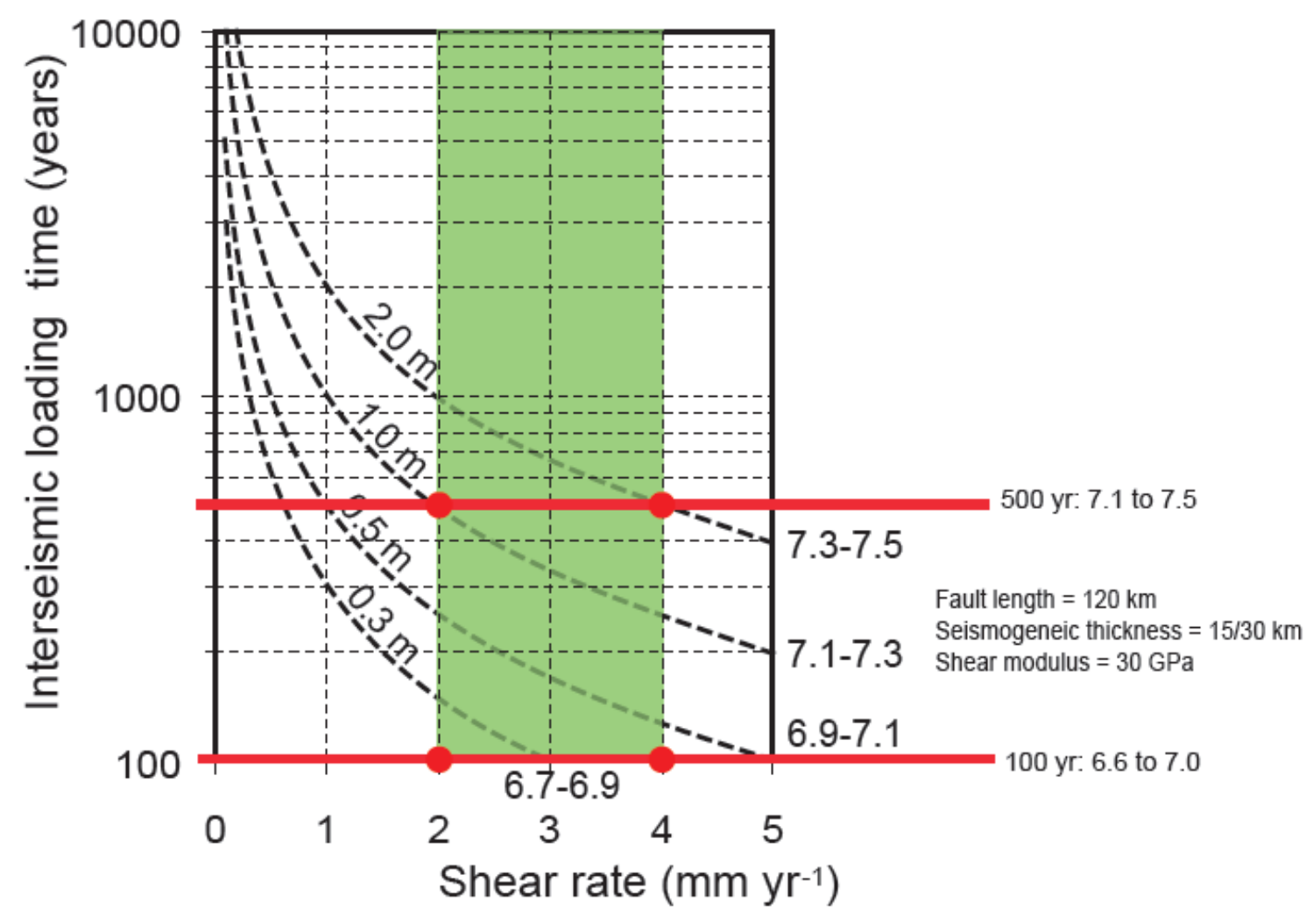

Figure 16 